\title{
Regulating the Diseased Society: Power and Moral Regulation in Public Health Discourse
}

\author{
By \\ Susan Joao \\ A thesis submitted to the \\ Faculty of Graduate Studies and Research \\ In partial fulfillment of \\ the requirements for the degree of:
}

Master of Arts
Department of Law Carleton University
Ottawa, Ontario
April 1, 2007

(C) 2007, Susan Joao 


$\begin{array}{ll}\begin{array}{l}\text { Library and } \\ \text { Archives Canada }\end{array} & \begin{array}{l}\text { Bibliothèque et } \\ \text { Archives Canada }\end{array} \\ \begin{array}{l}\text { Published Heritage } \\ \text { Branch }\end{array} & \begin{array}{l}\text { Direction du } \\ \text { Patrimoine de l'édition }\end{array} \\ \begin{array}{l}\text { 395 Wellington Street } \\ \text { Ottawa ON K1A ON4 } \\ \text { Canada }\end{array} & \begin{array}{l}\text { 395, rue Wellington } \\ \text { Ottawa ON K1A 0N4 } \\ \text { Canada }\end{array}\end{array}$

Yourfile Votre référence

ISBN: 978-0-494-26947-3

Our file Notre référence

ISBN: 978-0-494-26947-3

NOTICE:

The author has granted a nonexclusive license allowing Library and Archives Canada to reproduce, publish, archive, preserve, conserve, communicate to the public by telecommunication or on the Internet, loan, distribute and sell theses worldwide, for commercial or noncommercial purposes, in microform, paper, electronic and/or any other formats.

The author retains copyright ownership and moral rights in this thesis. Neither the thesis nor substantial extracts from it may be printed or otherwise reproduced without the author's permission.
AVIS:

L'auteur a accordé une licence non exclusive permettant à la Bibliothèque et Archives Canada de reproduire, publier, archiver, sauvegarder, conserver, transmettre au public par télécommunication ou par l'Internet, prêter, distribuer et vendre des thèses partout dans le monde, à des fins commerciales ou autres, sur support microforme, papier, électronique et/ou autres formats.

L'auteur conserve la propriété du droit d'auteur et des droits moraux qui protège cette thèse. $\mathrm{Ni}$ la thèse ni des extraits substantiels de celle-ci ne doivent être imprimés ou autrement reproduits sans son autorisation.
In compliance with the Canadian

Privacy Act some supporting forms may have been removed from this thesis.

While these forms may be included in the document page count, their removal does not represent any loss of content from the thesis.
Conformément à la loi canadienne sur la protection de la vie privée, quelques formulaires secondaires ont été enlevés de cette thèse.

Bien que ces formulaires aient inclus dans la pagination, il n'y aura aucun contenu manquant. 


\begin{abstract}
This thesis will highlight the theoretical underpinnings of the work of authors such as Deborah Lupton, Alan Hunt, Allan Brandt and Paul Rozin who analyze public health ideologies, practices and measures. A conceptual framework will be developed that will help explore and analyze the social, moral and political dimensions within current public health ideologies and discourse. Foucault's power/knowledge model as well as other concepts, such as risk, health, disease and governance, will be discussed in detail in order to understand the complicated relationship between morality, power and public health. Using historical and current accounts of epidemics, illness and disease as examples of political decision making and governing, it is argued that in light of these analyses, further reflection is needed when developing policies, discourse, programs and laws surrounding public health.
\end{abstract}




\section{Acknowledgements}

I would like to express my appreciation to my supervisor, Alan Hunt, whose subject knowledge, understanding, guidance and continuous patience, has resulted in a positive graduate experience. I would also like to thank my family for the encouragement and support they provided me throughout my life. My parents have taught me that life struggles are a test of strength, endurance and patience. Finally, must acknowledge my husband and best friend Jean-Philippe, who has endured me during this whole process. Without your constant encouragement, love and support, I would not have been able to finish this thesis. 


\section{Table of Contents}

Abstract ii

Acknowledgments iii

Introduction 1

Chapter One: Power, Governmentality and Health Promotion $\quad 10$

Governmentality 11

Public health and the regulated body 19

Chapter Two: Identity, Risk and Disease 30

Risk Identities $\quad 35$

Construction of Diseased Others $\quad 49$

Chapter Three: Regulating Health 56

The development of health theory 58

Morality and Health in today's society $\quad 75$

$\begin{array}{ll}\text { Governing Morals } & 79\end{array}$

$\begin{array}{ll}\text { Moralization } & 83\end{array}$

Canadian Public Health $\quad 88$

Canadian Public Health Approach $\quad 91$

$\begin{array}{lr}\text { Conclusion } & 99\end{array}$

$\begin{array}{ll}\text { Bibliography } & 101\end{array}$ 


\section{Regulating the Diseased Society: \\ Power and Moral Regulation in Public Health Discourse}

\section{Introduction}

Throughout history accounts of terrible plagues and illnesses rampaging and destroying different communities across the world have been told and imprinted in the social fabric of many societies. The impact of these diseases or plagues often brings about the uncertainties and the fear of future threats of other epidemic outbreaks and the detrimental effects these can leave behind. This fear of the 'inevitable plague' that will wipe out society becomes entrenched and part of life for many people who have experienced or fear the experience of being infected by disease. Recent examples of these debates around disease can be seen in media coverage of 'outbreaks' such as the AIDS epidemic, SARS in 2002 and just recently the global threat of the Avian Flu. On the surface, these fears about disease are about the direct effects of the disease on the body and any short term health and economic impacts people may experience. What is less visible and acknowledged, and can be even more detrimental, is the impact of disease on vulnerable and marginalized communities. It is the often the aftermath of isolation and stigmatization that can leave the most vulnerable populations crippled for a long time, and that often become neglected.

The initial and direct effects of these plagues and disasters are indeed detrimental. The newspaper and television images and the portrayal of people infected with SARS during the outbreak of this infectious disease outbreak 
demonstrated these short term impacts. What most people do not observe through these media images are the social responses to these outbreaks and natural disasters, and the specific effects on vulnerable groups most affected by the long term repercussions of these events. In the case of SARS the social panic felt in many cities lead to mass hysteria and subsequent irrational behaviour by some people. Such social behaviour often escaladed to actual blaming of the Chinese community in Toronto. This victim blaming of specific communities, ethnic groups and classes of people, and the construction of such 'risk populations', were outcomes of the SARS experience. Critics are thus concerned at the way that 'victim-blaming' discourse takes the focus away from important political, economic and social causes of ill health, for example poor working conditions and other environmental health issues (Lupton 1995).

In reviewing public health literature centred on issues such as health, disease and epidemics, it becomes apparent that the majority of the literature is scientifically based, written in traditional positivistic language and using the biomedical model as its basis of analysis. This dominant public health paradigm focuses its analysis using methods such as statistical measures, value-for-money frameworks, outcome evaluations and health promotion initiatives to explain, regulate and justify public health measures, initiatives, programming and political policy decisions. There is however a small group of writings that do attempt to explain and analyze public health issues within society in a more critical and conceptual manner. 
Authors such as Deborah Lupton, Alan Hunt, Allan Brandt and Paul Rozin analyze the political, moral and social implications of public health ideologies, practices and measures. These authors all emphasize the notion that public health ideologies and practices are not value-free and neutral, as the dominant discourse suggests, rather this discourse is historically specific, politically and socially contextual. This thesis will highlight the theoretical underpinnings of the work of these authors and attempt to develop a conceptual framework that will help explore and analyze the social, moral and political dimensions within current public health ideologies and discourse. Foucault's power/knowledge model as well as other concepts, such as risk, health, disease and governance, will be discussed in detail in order to understand the complicated relationship between morality, power and public health.

Using historical and current accounts of epidemics, illness and disease as examples of political decision making and governing, it is argued that in light of these analyses, further reflection is needed when developing policies, discourse, programs and laws surrounding public health. These discussions highlight the implications of social and political responses to infectious disease outbreaks. The social construction of what constitutes 'risk populations' and how this concept is defined are also analyzed. The ideas and perceptions behind what characterizes 'risk populations' often becomes part of the 'infected' community's personal and group identity during and often long after a health crisis. Throughout this paper, I argue that 'risk populations' are socially constructed and such constructions lead 
to the moralization of social group identities. The process of moralization of group identities can then have an impact on both the formal responses/policies to infectious disease outbreaks as well as on informal societal level responses which can result in health inequalities and social exclusion of these stigmatized communities.

The discussion concerning the process of moralization will provide some conceptual definitions of disease, identity and health. An investigation of some nineteenth century examples of disease exemplifies the social responses to infectious disease as well as analyze some more recent cases of infectious disease, or 'plagues', such as SARS, AIDS and the most recent example of the Asian Flu outbreak. This analysis will demonstrate how a disease becomes moralized and the 'infected' communities often become stigmatized. The process of 'moralization' as Allan Brant and Paul Rozin have coined the term, is less overt today but becomes more transparent upon closer examination and during times of 'health crisis'. During the process of the moralization of a health issue the potential social exclusion of the most vulnerable community members becomes a greater possibility. These 'moralized' and stigmatized social identities can have an informal influence in shaping more formal public health policies and therefore indirectly, or in some cases directly, reinforce societal responses of exclusion. I conclude by recommending that public health authorities should take a more reflective approach in developing policies, plans and programs that respond to infectious disease outbreaks. One suggestion could be to develop a community- 
oriented approach in responding to outbreaks, and so hopefully alleviate some of the stigmatization 'infected' communities often experience in such health crises.

In Chapter one Foucault's work concerning power and knowledge will be examined in relation to health and illness. Foucault's three major theoretical contributions to the social sciences all related to the issue of power; the power/knowledge analysis model, an understanding of the 'self' through disciplinary technologies, and an analysis of governmentality (Turner 1997). Once the theoretical groundwork has been provided, a closer examination of the issues surrounding public health and the regulated body will be analyzed. It is important to note that the ideological premise of public health within Western society is built upon the belief that the state's objective is to promote, achieve and maintain good health for all of society's citizens (Lupton 1995). In conducting and accomplishing the state's health goals, the state's role as a device in monitoring and actively participating in its citizens' best interest in order to improve and lengthen their lifespan becomes more apparent. This is perhaps most evident in regard to the question of health promotion. Concerns are growing around the idea of health promotion and the state's right to involve itself with the everyday lives and lifestyle choices of its citizens through institutionalized health programming.

Critics of health promotion believe that in order to improve the health of society, alleviating poverty, improving living conditions and the physical 
environment are key strategies for ill-health prevention (Lupton 1995). The solution would be to 'empower' citizens and heighten the awareness of sociopolitical and economic reasons for their disempowerment and oppression. Ideally this heightened awareness would encourage collective action against the powers of the state. This sets up a dualistic and coercive power relationship between the state and its citizens. Lupton argues that such a traditional model typifying a dualistic power relationship between the state and its citizens is too onedimensional and thus lacking as an explanatory tool for explaining the relationship between public health, the state and other social institutions such as the media and educational and legal systems and the individual or social group (Lupton 1995). Assuming that it is only the state that oppresses citizen's rights through public health and health promotion policies do not provide a complete an accurate picture of the power dynamics involved.

Chapter Two explores the concept of identity and how identity is constructed. The ways in which identities are constructed and why they are constructed in society will provide a conceptual background for understanding the narrower category of 'risk identities' or 'risk populations' in an infectious disease context. In explaining the concept of identity and how groups of people within the community become stigmatized, the general idea of concepts being 'socially constructed' needs to be understood. Social constructionism refers to the process whereby people actively construct their social world rather than have it imposed upon them (Abercrobie, Hill \& Turner 2000: 320). Therefore all human 
experiences are subject to social construction, and these resulting social interpretations shape their understanding, and thereby become a part of their knowledge systems (Berger \& Luckman 1966). The concept of health is a social concept that is constructed and reinforced in the everyday processes and structures of society.

1 argue in this chapter that the construction of 'risk populations' can indirectly create a category of marginalized community groups during a 'health crisis'. However in most cases these high risk communities are most often the marginalized communities within society, and so the mainstream social response can reinforce these inequalities that already exist. These stigmatizing notions about risk populations can be argued to contain 'Orientalist' notions of the 'other' as well as also consisting of moralized beliefs. Edward Said's idea of Orientalism will also be discussed in supporting the argument that these 'risk identities' are socially constructed and contain moralized ideas of 'otherness' (Said 1979).

In Chapter Three the relationship between morality and disease and how health is regulated will be discussed using historical examples of infectious disease outbreaks or 'plagues' and comparing these to more recent accounts of infectious disease outbreaks in Western society. These historical accounts, combined with the more recent examples of 'plagues' mentioned, will provide the contextual background needed to understand changes in disease theories since the nineteenth century. These indicate that there were changes in the thinking 
regarding disease, from the idea that disease occurred sporadically, and without warning infected the body and mind, to the idea that individuals are solely responsible for their own health problems. These ideas and beliefs about disease and illness all contain moral assumptions concerning disease and those infected by disease. This discussion leads into an examination of the process of moralization as described by Alan Brandt. This process will be explored using an example of how moral beliefs towards a particular ethnic community evolve. An attempt will be made to deconstruct the concept of what constitutes a 'diseased community' and demonstrate how a social group can become stigmatized and excluded through the process of moralization.

The final section of this chapter will discuss past and present public health responses to infectious disease outbreaks within North America. As discussed in the previous chapter, disease identities can have an indirect influence in shaping formalized public health policies and can have an impact on how community members receive social and health treatment during a health crisis. The Spanish flu of 1918 is one example of an outbreak that led to policies being developed in order to quarantine many communities that 'may' have been exposed. However, in some historical accounts of the Spanish Flu the reality was that many marginalized groups were assumed to have been exposed and so were socially and physically systematically excluded from the rest of society. A similar reaction can be observed with the recent case of SARS and the Chinese community of Toronto. The Chinese community experienced social exclusion and 
stigmatization from mainstream society due to the moral panic generated by heavy media coverage. Public health policies regarding SARS lacked the capacity to deal with the situation without creating social and health inequalities that were felt by the Chinese community. Current public health frameworks will be analyzed in this chapter and the recommendation given that public health responses need to take a more bottom up approach during a health crisis. I conclude by arguing that 'we' as individuals within society need to proceed with caution and be aware that 'risk identities' are socially constructed within a disease context. This can lead to the potential outcome of stigmatization of vulnerable communities and social isolation from the rest of society. 


\section{Chapter One: Power, Governmentality and Health Promotion}

The Western system of medical knowledge is often referred as to the 'biomedical' model and it is widely accepted as being neutral, scientific, value-free and unbiased. It is argued however that the bio-medical model, as well as other related discourse models, such as health promotion discourse, is socially constructed. This means that these knowledge-based systems and models are cultural products and these ideas and practices change based on the social, economic and political status of the society in question as it exists in a given time-period. Within the biomedical model, knowledge, discourses and practices create their objects and interest. Concepts such as disease, illness, patients and medical techniques regulate ideas of what is considered 'normal' and what counts as 'risky behaviour'. Analyzing these concepts demonstrates that moral judgments do exist within public health discourse and therefore complicate the relationship between power and knowledge further in regard to this domain (Lupton 1995:4).

In today's secular society, health status has become a measure of one's accomplishment. Health has become the new alternative to religion and prayer in providing people with a means to define their own lifestyle. It can be argued that health promotion contributes to the moral regulation of society because it focuses so frequently on moral and ethical self-regulation of the body (Lupton 1995, Hunt 1999). There is no argument that with the rise of health promotion in Western 
society have come also improvements in health status at the societal level (Public Health Agency of Canada 2006). However, a critical analysis of the ideology underpinning public health and health promotion needs to be undertaken in order to understand how ideal subjects are created, often creating a binary opposition that can be linked to moral and discriminatory judgments, as well as to the concealment of the political beliefs of social institutions.

the ways in which the practices and policies of public health and health promotion valorize some groups and individuals and marginalize others. The concept of subjectivity and rationality they privilege and exclude the imperatives emerging from other socio-cultural sites that intertwine and compete with those of public health and health promotion and the discursive processes by which these institutions are constituted and supported (Lupton 1995:5).

\section{Governmentality}

The concept of governmentality provides a means to understand the social and political role of public health discourse and practices. Governmentality incorporates practices of self-governing but also the more apparent forms of external governing, such as policing, regulatory activities, and surveillance carried out by the state or institutionalized agencies for strategic purposes. The underlying principle of governmentality attempts to 'normalize' the idea of being governed through disciplined practices, knowledge and technologies in regard to how individuals should conduct themselves. The concept of governmentality does not just look at the state as an overarching power seeking to constrain the lives of its citizens. Rather it sees power relations as diffuse and emerging from 
all areas of social life and directed towards a plurality of specific aims (Foucault 1991:95).

Foucault's power/knowledge model states that power is situated among the conflict of everyday social relations and practices. Within these social formations, discourses are manifested in an economy of discourse to which power is directly connected. Obtaining and having knowledge becomes a privilege within society. Being able to have such knowledge, and thus be in a position to make statements and pass them on to others as "truths", involves notions of power. Speech becomes an inter-subjective exchange with knowledge as its object and its 'other', the person whom the knowledge will be exchanged with or passed on to, as 'truth' (Allen 1999:71). Knowledge becomes an "economy" of statements similar to that of monetary exchange, "the value of knowledge is no more than its currency, has no more to do with things in themselves than does money with the value of its paper or metal" (Allen 1999:74). Discourse within the social structure brings power to existence. Power can either provide credibility to the ideology or become a 'hindrance' for those who 'have' the power. Foucault states that,

Discourses are not once and for all subservient to power or raised up against it, any more than silences are. We must make allowance for the concept's complex and unstable process whereby discourse can be both an instrument and an effect of power, but also a hindrance, a stumbling block, a point of resistance and a starting point for an opposing strategy. Discourse transmits and produces power; it reinforces it, but also undermines and exposes it, renders it fragile and makes it possible to thwart it (Foucault 1980:100). 
Discourses become an important dimension of the power relations between social and political institutions, communities and individuals. A fundamental part of Foucault's power/knowledge model is the tendency to believe that people who are in a position of power also have specialized knowledge that the majority of others in society do not have. Therefore the reciprocal nature of Foucault's power/knowledge model becomes evident as the production of knowledge and the exercise of administrative power interconnect. For Foucault this reciprocal connection reinforces the relation between the circulation of knowledge and the control of conduct (Allen 1999). Foucault would argue that power is not possible without knowledge. For example, having specialized knowledge in the field of health would allow public health authorities such as medical scientists, doctors and health policy makers to have unique power and control over the 'truths' under riding public health issues. This type of power relation is dependent on the economy of discourse to sustain its authority and is confirmed when the media's assertion that these 'truths' emanating from health authorities are unequivocal facts, such as occurred during the SARS outbreak. These statements become power when transferred and carried through to the rest of society.

Broadly defined, Foucault's concept of governmentality is the 'art of government'. The notion of 'government' is not limited only to state politics, however. This includes a range of control technologies and can be applied to a variety of objects, including to one's own self. This concept was further 
elaborated by authors such as Nikolas Rose and Mitchell Dean.

'Governmentality' applies to a variety of historical periods and power regimes. However Foucault and others often applied this concept particularly to 'neoliberal governmentality', where society is said to be characterized by decentralized power relations and its citizens to play an active and important role in their own self-governing. Under this type of power relationship, individuals are regulated internally, meaning that individuals govern themselves and the source of power itself is to govern from a distance (Dean 1999, Lemke 2002, Rose 1996, 1999).

Hunt's and Wickham's work Foucault and Law (1994) provides a useful definition of governmentality; they state that, "governmentality is the dramatic expansion of the scope of government, featuring an increase in the number and size of the governmental calculation mechanisms" (76). Hunt and Wickham state that governmentality arose in the mid-eighteenth century and was closely aligned with the growth of modern bureaucracies. Governmentality pertains to the study of the government of a country. Dean agrees with Hunt and Wickham's idea of mentalities of government and elaborates the concept to incorporate the idea of government rationalities. Dean defines governmentality as "how we think about governing others and ourselves in a wide variety of contexts (Dean 1999:212). This definition reflects Foucault's ideas about how individuals or groups of people conduct or govern. Dean states that to analyze government is to analyze the mechanisms that attempt to shape, influence, and mobilize the choices, 
lifestyles, passions and desires of individuals and groups within society (Dean 1999:12).

Dean expands the concept of governmentality by stating that this concept is not simply a tool for thinking about governing mechanisms but also about how people who are governed think about the way they are being governed through different 'technologies of power'. This latter term is defined by Rose as those "technologies imbued with aspirations for the shaping of conduct in the hope of producing certain desired effects and averting certain undesired ones (1999:52). Dean defines this idea as "collective activity", that is the collective knowledge, beliefs and opinions held by people who are being governed in some fashion or other. He raises an important point in that people who are governed may not always understand that they are being influenced and they may 'choose' or take for granted activities and lifestyles. Dean explains,

On the one hand, we govern others and ourselves according to what we take to be true about who we are, what aspects of our existence should be worked upon, how, with what means, and to what ends. On the other hand, the ways in which we govern and conduct ourselves give rise to different ways of producing truth (1999:18).

The idea of self-governing is an essential component of the concept of governmentality. Through the idea of freedom of choice, self-governing capabilities can be embedded within that which will allow for self-regulation but will also result in being in line with political objectives (Rose 1996:155). Rose describes these capabilities as enterprise and autonomy. Enterprise is defined as an array of rules for the conduct of one's everyday life's ambition, personal 
responsibilities and initiatives effected to shape one's life so as to maximize its own human capital. Autonomy is defined as taking control of our undertaking, defining our goals and achieving those goals though our own powers (Rose 1996:159).

In Rose's analysis of health he argues that public health objectives for good health and good order of the social body require the desire of individuals to achieve that objective (Rose 1999:74). Rose clarifies this power relationship and argues that this wave of "healthism" is not likely a complete consequence of state planning. The state does play an important role in calculating its objectives. However the state no longer seeks to discipline, moralize or impose on individuals in order that they comply with their objectives, rather this rise in focus on public health issues comes from the power of the 'experts'. These experts play an important role in governing individual and group conduct in regard to health. It is the experts who 'advise' and 'recommend' individuals about how to conduct themselves in order to maintain healthy lifestyles. These politically defined ideas regarding health are advertised to individuals as principles that require adherence in order to achieve one's personal goals. Rose argues that these goals are aligned with political goals and therefore individuals and groups are governed from a distance (Rose 1999).

In the context of public health the concept of governmentality incorporates both coercive and non coercive strategies. The state plays an important role for 
the structure of power relations within society, as do other social institutions, social groups and communities whose concerns and activities may support or conflict with the imperatives of the state. Health discourse is presented as 'truths' and claims that adherence to such practices are for our own good and best interest. The health 'experts' in society, doctors, scientists, epidemiologists, etc., play an important role in the process of 'normalization', which is defined as attempts "made to construct a privileged type subject through the web of expert judgments surrounding the body" (Lupton 1995:10). These experts measure the population and establish trends and norms which then serve as bases of comparison. Their role is to mediate between the authorities and individuals, influencing people's habits and choices through their own acquired knowledge. It is argued that experts have the power to manage individual behaviours to achieve social goals which are often of political concern, and which can generate new 'problems', via which experts can reinforce their own role by solving them with their expertise (Lupton 1995).

Through the use of the example of health promotion, ideas of governmentality can be explored. Health promotion can be seen as a government mechanism to influence the shaping of individual behaviours to conform to the government's current objectives. This is done through a closely linked network of 'experts' that dispense their knowledge to improve individuals' health through self-regulation. Often times these 'experts' generate their findings through research grants shaped and funded by government's current priorities. 
The public health institute, similar to the education system, does not present itself as coercive because it appeals to widely acceptable norms (Lupton 1995:10). However, if this expert advice is not taken, 'punishment' through self-scrutiny can evoke feelings of guilt and repulsion upon oneself for inviting illness to occur, as well as an unsympathetic gaze from the rest of society. The notion of governmentality 'invites' individuals to volunteer themselves, through the idea of choice, into conforming to societal objectives by self-regulating themselves via practices that achieve those goals. People constrain themselves with a moral code of what constitutes a 'good person', constantly looking to improve oneself either by means of health, social status, wealth, etc. These health promotion goals are proliferated by the state and supported through institutions such as the mass media, the educational system, family, community organizations, etc.

In Watts' book "Epidemics in History: Disease, Power, and Imperialism" the author critically examines the effects of the great pandemics of our time. Watts argues that many social, political and moral factors influenced the ways in which societies implemented and conducted their policies and responses to pandemics. Indeed the impact of a disease is linked to the distribution and implementation of power. These administrative decisions resulted in significant effects on the course of the epidemic. It is during these times that dominating power relations reinforce socioeconomic inequities on all levels of society. Watt states that moral standards in many cases served to justify discriminatory ideas and allowed European elites to tolerate and ignore the suffering and death the 
plague caused people in inferior social classes, groups or castes (Watts 1997). For example, according to Watts' investigation on the spread of syphilis, moral beliefs concerning sexuality played a role in the spread of the disease. For example, during the syphilis outbreak masturbation was condemned yet prostitution was condoned, thus worsening rather than improving the situation.

\section{Public health and the regulated body}

In today's society, the modern individual is subjected to the idea that one's appearance and behaviour are reflective of their identity, and this results in the burden of controlling the emotions in an effort to discipline the body, effected through societal ideals and standards. The body is seen as mirroring the inner self, and if the body appears uncontrolled then the self also appears as undisciplined, both to the individual herself as well as to the rest of society (Lupton 1995:7). The discipline and 'civilized' body constructed through dominant standards and beliefs are considered to be a close reflection of the dominant culture, while the undisciplined body that indulges in bodily pleasures and urges is seen as an uncontrolled and impure (Lupton 1995:8).

This section will examine the way in which health promotion discourse incorporates moral constructs of the subject and the choices the subject makes. The medical field and morality are intertwined, health promotion provides an example in which self-regulation becomes a conduct of appropriate and accepted 
behaviours. Health promotion initiatives portray the idea that rational and virtuous citizens will regulate and monitor their lives consistent with an ideal lifestyle. In most cases, the individual will 'choose' to behave in a certain manner and not expose themselves to stigmatization from the rest of the community. In analyzing the health promotion model, it becomes clear that notions of rationality, conscious decisions made about one's lifestyle and habits, gestures for selfimprovement and social success are all part of the discourse. One is required to master and have self control, otherwise the threat of sickness becomes a bodily social marker revealing one's fragility and closeness to mortality (Lupton 1995:9).

Exploration of the arena of the body is becoming an important topic in governmentality studies. The body is used as a sphere wherein connections between illness, disease, culture and self-regulation all intertwine (Lupton 1994). Turner argues that society is now less concerned about and focused on increasing the production of the population than it was in the past and more concerned with regulating bodies themselves (Turner 1992). Foucault's concept of governmentality has provided insight into the way in which technologies of power are masked by the idea of individualization, meaning that individuals constantly re-examine their 'inner self'. He viewed this self-evaluation as an obligation rather than an individual, free choice (Foucault 1980). In discussing the idea of the body it is important to note that the definition of the body that is being used to explain Foucault's notion of power is one that recognizes that the body is both biological and social in nature. Discourses have the influence to 
shape bodies and experiences, people also have a degree of control in doing this through their own choices, in labour and leisure activities. Foucault recognizes that the body is a site of power struggles and that power does not exist independently of the body and self, but rather acts to construct the body (Foucault 1980). For example the discourse and practices around health promotion serve as a means through which people live, practice, engage, understand and articulate their lives.

The concept of subjectivity or the 'inner self' is central to an understanding of the ways in which people negotiate the imperatives of health promotion. Subjectivity can be defined as a sense of self or self-identity and it is socially constructed through interactions with citizens. Language and discourses such as that of health promotion are key in the construction of the self and how one embodies experiences. Subjectivity is dependent on the context and individuals are not always completely 'free' in their choices, because subjectivity is constructed through and articulated by power (Foucault 1980). For example gender often contains assumptions of masculinity and femininity out of which an individual constructs his or her identity, however the 'choices' will always be constructed within gender boundaries, and within that time and social context.

It has been argued that public health and health promotion are governing mechanisms of moral and self regulation. These mechanisms serve to draw distinctions between 'civilized' and 'uncivilized' behaviours and promote the 
notion that the human body is separated from the mind/will. Civilized bodies are in need of careful management and control and thus also represent certain social groups as uncontrolled and threatening 'others'. It is considered that to achieve the civilized body is to achieve the ultimate body. Government state and social institutions do not necessarily overtly coerce their citizens into following dominant practices that are deemed 'civilized', however Lupton argues that the body is a site of struggle and constant regulation of meaning and practices (Lupton 1995:12). The link between morality and the self-regulating subject intending to discover the 'authentic self', is historically and culturally specific.

Turner observes that in the area of medical sociology, two important interrelated developments have had a great impact in this field of study. The first important impact was Foucault's analysis of power/knowledge which has influenced a range of studies about health. The second important development was the emergence of the sociology of the body as an underpinning for medical sociology (Turner, 1997). Turner argues that these two theoretical developments 'pushed the discipline away from medical sociology towards the sociology of health and illness, that is towards a critical epistemology of disease categories as elements of a moral control of individuals and populations" (Turner 1997:VIV). Foucault's work highlights the importance of regulation as a key feature in modern society. Turner argues that Foucault's governmentality ideology contributes to the risk discourse by stating that; "as the global economy develops into a culture of risk, the nation-state is forced to invest more and more in internal 
systems of governmentality ... a risk society, based on deregulations and devolutions, often requires more subtle and systematic forms of control" (Turner 1997). Notion of generalized risk in the environment may lead to greater surveillance and control through the promotion of preventive medicine. For example the AIDS 'epidemic' create political climate within which intervention and control are seen to be both necessary. Individuals' needs, especially in the area or sexual etiquette, were self regulated and self-forming.

Alan Peterson argues that Foucault's writings on governmentality laid the groundwork for an analysis of risk as a political technology. Peterson analyzes Castel's 'From dangerousness to risk' because it highlights the role of expertise in the administration of populations and the regulation of personal identity (Peterson 1997:192). Castel explores the new preventive strategies that have emerged in modern society, especially in the area of public health. Castel argues that over the past hundred years, there has been a shift from controlling 'dangerous individuals; using face-to-face interventions and the use of confinement to regulate and control disease outbreaks, illnesses and deviant behaviour. This shift to a more subtle and effective mode of population control focuses on risk factors rather than on the individual themselves. Health experts have constructed new risks that target populations for preventive intervention. However, Castel cautions that the social and human cost to these new "witch hunts" are not always reflected or apparent (Peterson 1997:193). Castel examines current prevention and risk discourse in relation to political techniques 
and ideologies. He also argues that new preventative strategies are part of a set of new regulation and management techniques that assign a special economic and social 'destiny' to certain categories of individuals who possesses political will.

This sort of internalized regulation occurs in today's neo-liberal society. Peterson defines neo-liberalism as "a form of rule which involves creating a sphere of freedom from subjects so that they are able to exercise a regulated autonomy" (Peterson 1997:194). Neo-liberal regulation is connected to a form of rational self-conduct that is motivated by interest and ego. Neo-liberalism requires individuals to engage in the process of their own self-governance through the process of continuous self-examination and self-improvement. This ideological shift from the idea that the state should protect their citizen's health to the idea that it is the individual's responsibility to protect themselves from risk and risky behaviours is apparent with health promotion goals and strategies. In examining health promotion initiatives, it can be observed that the process of risk management distributes responsibility for managing risk onto individuals as well as creates a mechanism to regulate their private lives.

Contemporary health promotion incorporates community participation and education about health issues, influencing the promotion of what is considered 'unhealthy' and dangerous products, regulating urban spaces, implementing interventions and monitoring of populations. Castel observes that this form of 
regulation is justified on the basis of the calculation and probability that risky behaviour can be prevented. Health promoters work from a distance and are not viewed as directly intervening, but rather working collaboratively for program and policy development, promoting community capacity with public and non-profit organizations. Health promoters such as the Public Health Agency of Canada and Health Canada implemented different kinds of initiatives at different levels of intervention in collaboration with the public and private sector, while fulfilling the World Health Organization's goal of 'health for all'. Health promoters have taken the role as expert mediators with their efforts in controlling risk factors. Therefore, health promoters are viewed as being in line with health movements that concerned with 'empowering' its citizens (Peterson 1997:196)

The notion of self-management of risk and self-care are embedded in health promotion initiatives and discourse. This manifestation has been recognized as being a part of the 'healthism' phenomenon in neo-liberal society. Healthism refers to the belief that individuals have a choice in preserving, prolonging life and preventing illness or disease. If one is unable to regulate and manage their lifestyle and eliminate risky behaviour, then they are viewed as failing in their own self-care (Peterson 1997:198). The terms 'healthy' and 'unhealthy' have become significant identifiers of what is considered normal and abnormal identities with moral connotations attached. Peterson concludes by stating that it is wrong to assume that domination of individuals is complete and coercive, utilizing mechanisms of relation control. The use of the governmentality 
concept "allows one to acknowledge the complexities, subtleties and micronegotiations of relations of power and involves recognition that any project of governance is always incomplete and partial in respect to the objects and practices it governs" (Peterson 1997:203).

McGillivray's article "Fitter, Happier, More Productive: Governing Working Bodies through Wellness" addresses the concept of organizational wellness in the work environment as well as the idea of the self-regulating subject. McGillivray uses Leichter's definition of wellness as affirming virtuousness, achievable through a preoccupation with health, the underlying message being one of being or becoming more "well" (McGillivray 2005:125). McGillivray expands the idea of organizational wellness further and states that it encompasses both the language and practices which institutionalize workplace health promotion programs in organizational settings, which include health, safety, smoking, alcohol, healthy eating polices and the promotion of exercise at work (McGillivray 2005:126). McGillivray proposes an alternative analytical framework drawing on Michel Foucault's ideas about governmentality and the subject, with a view to providing further insight into organizational wellness.

The concept of organizational wellness has evolved from the traditional Fordist model which include inspectors visiting the home of workers to monitor compliance with strict health procedures, and extends up to a contemporary notion whereby each worker becomes their own inspector (McGillivray 
2005:135). Using Foucault's governmentality model, McGillivray argues that the discourses of organizational wellness cannot simply be seen as performative but rather contain imperfect governance arrangements. He states: "Ever-present conflict, contestation and resistance then prevent the translation of macro wellness messages into concrete effects at the local, organizational level" (McGillivray 2005:135). There have been a variety of responses to organizational wellness in the corporate environment, demonstrating a spectrum of selfgovernance habits. He concludes by stating that organizational wellness initiatives are there for a particular reason in the workplace, such as functioning to enhance productivity. However, he rejects the idea that all employees are passive receivers of wellness discourse and initiatives (McGillivray 2005).

Throughout Saguy and Riley's examination of the obesity debate, they found that the scientific methods and empirical facts used in framing such arguments were morally based. These arguments had important implications for social inequity. Saguy and Riley argue that "framing obesity as risky behavior may serve to legitimate social inequality and health disparities" (Saguy \& Riley 2005:912). For example, if obesity is recognized as visible evidence of "bad" food choices and laziness, individuals are often blamed instead of the impact of structural issues such as poverty, violence and lack of medical insurance being considered as causes of poor health (Saguy \& Riley 2005). This obesity epidemic represents the spread of poor and immoral behaviour around the lack of control in the vicinity of food. In this context, medical knowledge becomes a moral 
authority, declaring obesity an "epidemic" in society that often undermines "obese" people. Unlike "improper" behaviours such as smoking, drinking or sexual promiscuity, obesity is a stigmatized physical characteristic. The issue of obesity is also likely to reinforce negative responses to a visible and stigmatized group. These health risks become a part of the surveillance function which Saguy and Riley argue shifts the medical gaze from the individual to the whole population, and "encourages" obese individuals to take control and adopt appropriate behaviours and habits regarding their body.

Drawing on Saguy and Riley's assessment of the obesity debate in the United States, a Foucauldian analysis can be applied. In utilizing Foucault's governmentality concept, attention can be drawn towards the way in which the obese subject is produced and chosen. Obesity is an example of a health promotion initiative that provides a means by which subjects assess themselves using experts' knowledge. Foucault's work is essential in such an analysis since he was concerned with the means by which individuals construct and discipline themselves with the 'proper' or 'correct' way of behaving in society. As mentioned previously, this expertise is used as a means to 'control' individuals' 'choices' from a distance. Saguy and Riley's analysis of obesity debates emphasize that obese individuals do not follow the dietary recommendations as set out by health experts. This scientific groundwork in public health initiatives often becomes part of the accepted social fabric of society. As Crotty argues, nutritional promotion is criticized because it "lacks a social perspective and compassion" and as it does 
not take into consideration the everyday realities that impact and influence people's choices surrounding nutrition (Crotty 1995:1).

Foucault's analysis of governmentality provides a framework to understand the complexities of health governance in society. In attempting to normalize the idea of being governed through health promotion practices and initiatives, individuals internalize the way in which they 'should' conduct themselves. It is through the idea of 'freedom of choice' that self-governing capabilities are embedded in public health initiatives, often in line with political objectives (Rose 1996). Chapter two's discussion on the construction of identity and 'otherness', provides further details on how communities are identified and often stigmatized. Notions of governance, governing from a distance and power all contribute to the inter-play between the concept of risk populations, morality and health. 


\section{Chapter Two: Identity, Risk and Disease}

In analyzing health and illness discourses, the concept of identity becomes crucial in understanding how individuals identify themselves, selfregulate, monitor, behave and label themselves and others. It is in this relationship between the construction social groups and regulating health that Foucault's power and governmentality framework can be observed. There are many different definitions of the concept of identity. Social identity can be different from personal identity depending on its context. The theory of social identity formed by Henri Tajfel and John Turner (1986) states that everyone in society belongs to some sort of group and that people derive part of their identity from their association with that particular social group. Individuals also enhance their personal identity by comparing themselves to others who are not part of the group with which they associate. Tajfel and Turner's social identity theory was developed in order to explain why individuals identify with and participate in social groups. Oftentimes individuals in these social groups develop, and share beliefs and attitudes towards other individuals and groups outside their own group, community, society, etc. Charles Rosenberg argues that throughout history notions about the causation of disease have been connected with identity (Rosenberg 1997:35). Simple correlations between specific risk and health outcomes are often too simplistic in analyzing the social and emotional impact on individuals. 
The social identity theory is also concerned with the social interactions between individuals of the same group and acknowledges that there can be sociological as well as psychological aspects of behaviour within and outside their group. According to this social identity theory, the process in which people develop their identity is comprised of three elements; categorization, identification and comparison (Tajfel \& Turner 1986). Briefly, the concept of categorization means placing others as well as ourselves into social categories. For example, labeling people by ethnic origin, race, and gender, or even by what activities they practice are all forms of categorization. Identification occurs when people associate with a certain group or groups and this identification facilitates in part their own identity, self worth or self-esteem. Comparison occurs when people compare the group with which they associate themselves with other groups. When comparison occurs, personal biases are often used and the individual usually favours the group(s) that they themselves associate with (Tajfel \& Turner 1986).

Tajfel and Turner's definition of identity combines elements of self-identity derived from individuals' personal characteristics as well as those elements derived from participating and being a part of a social group(s). Each person can be said to have multiple identities depending on how they define themselves. Nevertheless, the identity that is most significant for that particular person can change over time and according to the social environment in which the individuals are situated. Personal identities emerge in the context of personal 
relationship with others and social identities are more likely to emerge in contexts where group behaviours are more apparent (Tajfel and Turner 1986).

The concepts behind the three elements of social identity can be used to further explain how identities are constructed within a health context. The first element of categorization was used to explain the fact that people categorize objects in order to understand them more clearly, which includes the categorization of other people but also of themselves. Social labels are used to assign people to these pre-assigned categories in an attempt to describe characteristics about the people in that group. For example, in a health context people can be categorized according to their health occupation and labeled as doctors, nurses or patients. By categorizing and understanding people in other groups, we are able to classify our own characteristics. Once individuals and groups become categories, social interactions or behaviours are developed. Using the categories of doctors and doctor and patient, different social interactions are associated with these roles in a hospital environment. When people go to a hospital to visit someone who is sick, there are set behaviours and norms one unconsciously plays out while they are there. Associated with this line of thinking and interacting, there is also the belief within society that the doctors there are the only experts and have all the knowledge of how to heal their patients (Tajfel and Turner 1986).) 
The second important element of social identity is identification and this concept can be described in two ways. The first way of defining identification is when thinking of ourselves as fitting into an 'us' vs. 'them' framework, while the second way of doing this is in terms of 'l' vs. 'him/her'. Sometimes people identify themselves as part of a group and at other times people think of themselves as independent individuals. It is important to note however, that people can think of themselves as both group members and as individuals and this contributes to one's own self identity. Within a health context an individual can be part of an identifiable health category, such as a group that may have high risk of certain diseases like cancer or heart disease. An individual can also label themselves as 'healthy' and others around them as 'inactive' or 'obese'. Some of these labels carry moral views and beliefs about 'others', such as in the case of labeling someone as 'obese' and believing that 'they' are lazy.

Part of the identification process also involves the fact that 'we' are similar to the group we associate with and that we treat members of our group as being similar to ourselves. This can also be said for treating 'others' differently and the notion that people outside the group you associate with can also be treated in a certain manner. Referring back to the example of obesity, if someone labels themselves as 'active' or 'slim' there is a tendency to view others who are not similar as 'over-weight' and 'lazy', not taking into consideration any other factors that may contribute to their being 'over weight' and thus treatable in a prescribed way. 
The third element involving comparison has already been touched upon briefly when describing the other two elements of social identity. The idea of social comparison is basically the belief that in order to evaluate who we are as individuals there needs to be a comparison made to others who have 'comparable' characteristics. Comparison to others can be done in two ways; positive distinctiveness and negative distinctiveness (Tajfel and Turner 1986). Positive distinctiveness is the motivation to view the individual's own group as 'better and superior' to other similar but 'inferior' social groups. Negative distinctiveness describes the process of minimizing the differences between the groups so that your own group is seen in a more favourable light. Thus, groups can choose to maximize certain elements that are perceived to be of 'high status' and use those elements as a means of comparison with groups of 'lower status'. This will minimize elements viewed as non-appealing but attempts to maximize other dimensions. For example, some people who choose 'bad health habits' will not want to bring attention to the fact that they smoke or do not exercise as part of their identity but might regard their way of life as coming under the rubric of being free to make the health choices they want, in contrast to the fact that they may be risking their health status in the future.

Social theory demonstrates that individuals will categorize themselves as possessing a group membership and will internalize and seek positive selfesteem by differentiating their group through comparison to another group. This 
form of comparison is usually based on some form of characteristics that the group sees as 'valuable' and considers a membership requirement. Tajfel and Turner also suggest that if there is conflict between groups it is more likely that individuals will judge one another on their group affiliation and commitment rather than on [the] individual characteristics. This social identity theory also extends to intergroup competition, which is often motivated by rewards and in turn enhances the group's morale, cohesiveness and cooperation.

\section{Risk Identities}

In using Tajfel and Turner's analysis of the social construction of social groups within society, this section will undertake an examination of what constitutes 'risk' and the construction of 'high risk populations. The comparison between the constructions of at risk populations to the rest of 'healthy' society is an important comparison to analyze in order to understand the formal and informal responses to these risk populations. The central underlying premise around the concept of risk population is the conflicting ideals of what is considered 'pure' or 'healthy', i.e., that which is seen as 'tainted' or 'diseased'. The notions around what behaviours, habits and social interactions are considered 'risky' within society can assist in the development of orientalist beliefs about these 'at risk' populations based on health issues (Sandford \& Ali 2005). Analyzing the beliefs surrounding risk populations clarifies the point that there is an assumption that risk is created without any social values and that 
people belonging to these risk populations always have a free choice regarding their exposure to these risk factors. This belief about people always consciously choosing to be exposed to risk can lead to discriminatory beliefs emanating from the dominant social groups, towards the more vulnerable and marginalized groups in society (Sanford \& Ali 2005). This process could be observed during the SARS outbreak in Toronto in regards to the marginalization of and discrimination against the members of the Chinese community.

The concept of risk is essential in the social control process and perception of legitimization of public health ideals (Armstrong 1995). The concept of risk is categorized into signs, symptoms and types of behaviours that are classified as "risk factors" which in turn represent the potential for the occurrence of disease rather than the actual occurrence of disease (Armstrong, 1995). These risk factors are then imposed onto a group of individuals within society, or a risk population. This process of labeling a risk population is similar to the process of "othering". Defining a risk population is based on "potential risk factors" determined by "expert scientific knowledge", by professionals who are institutionally trained.

The concept 'risk' has become a large part of the public health language, along with other coined terms such as 'risky behaviours' and 'risk groups'. The shift of monitoring the population for "risk factors" indicates that there was a shift from believing that the disease emerged from the individual body to thinking that diseases are now likely to emerge from a population group and its related spaces 
within society (Armstrong 1995:395). The seemingly neutral description of "risk factors" can implicitly result in labeling risk groups as responsible for the cause and spread of the outbreak of an infectious disease. The perception of "risk groups" as being objective criteria often leads to the idea that individuals have the choice regarding their own exposure to health risks and environments. The social exclusion of risk groups/populations often overlaps with that of minority groups within society. The labeling of the AIDS risk group, its identification with the gay population, reinforced discriminatory attitudes towards the gay community as well as inadequate understanding of the disease itself (Armstrong 1995).

Fischer and Poland argue that concept or risk is an important mechanism for social control of public health discourse (Fischer \& Poland 1998). Within this interpretation of risk, and using Tajfel and Turner's ideas of categorizing and comparing social groups, the process of 'othering' of risk populations becomes explicit. This distinction between what are considered risky behaviours vs. safe behaviours can further develop moralized attitudes towards marginalized groups. The categorization of risk populations serves to control risk through public health emergency management and surveillance frameworks. In Fisher and Poland's analysis of' social exclusion mechanisms, they argue that much of the literature around health surveillance has ignored issues concerning power, marginalization and social control (Fisher \& Poland 1998:187). Traditional theories constructed to explain processes of power and control have been conceptualized as visible 
interventions and negative sovereign power exercised at the state level. Contemporary theories of power and control have focused less on such punitive mechanisms of disciplining. Foucault's work looks at self regulation as a powerful device often exercised in a discrete but effective manner and which becomes internalized. These control mechanisms are often located outside formal processes of law and regulations (Foucault 1979, Hunt 1993).

The processes of social exclusion are a crucial part of social control and governance in modern society. The risk management of infectious disease has developed into a mechanism of social control under the governing umbrellas of local public health and safety administrations (Fisher \& Poland 1998). This can be observed in governance based around the ideas of 'risks, prevention, responsibilities'. The objectives of eliminating risk and disorder have led to individuals becoming the main targeted site for exclusion and control. Risk behaviours that are associated with different groups can be viewed as deviant behaviours and not part of the accepted social norms for health. These health norms act as a form of informal control of these risk populations and of certain social spaces within society. Therefore, constructing risk populations is a vital component in continuing and sustaining compliance from the rest of society (Fischer \& Poland 1998).

The fields of public health and disease surveillance have become a new focal point of control by health professionals, police and citizens (Fischer \& 
Poland 1998:188). In some cases such as in the case of SARS, efforts to address risk reduction by local health policy aiming at 'public' environments can impact upon marginalized social groups and must be recognized that this can further exacerbating social inequalities. These controls are often less visible and hidden in the everyday practices of social life. Nettleton and Bunton (1995) argue that the construction of risk itself becomes a technique of governance because it contains ideas of self regulation, personal responsibilities and self control. This "moral" code of health promotion implies a set of civic duties and values for individuals to manage at their own risk, but also the risk of affecting others. Therefore, this system of social practices of risk management becomes entrenched in our everyday lives and shapes the way we think of ourselves and others, often becoming moralized beliefs, as in the case of second hand smoking. Oftentimes stigmatization becomes a consequence of practices of exclusion based on the desire for risk prevention (Fischer \& Poland 1998: 195).

The social construction of risk is a selective process, while certain forms of risk taking, such as smoking are seen as "bad", other forms of risk taking such as a heterosexual male having unprotective sex or participating in extreme sports do not garner as strong a reaction from the public. Smoking can be seen as a part of a larger social history of the purification of public space in which middle class professionals seek a risk-free space (Fischer \& Poland 1998, Armstrong 1995). Smoking has rapidly come to be seen as a deviant practice, especially in public spaces, which is seen as a visible marker of moral weakness and social 
incompetence. Foucault's idea of the 'panoptic gaze' can be used here to illustrate the successful internalized moral beliefs surrounding smoking and how this 'gaze' from non-smokers becomes a means of social control (Foucault 1991). This 'panoptic gaze' of social exclusion is similar to Edward Said's concept of orientalism and the gaze (Said 1979). For example, smoking policies at many restaurants and universities do not allow for any designated smoking areas. People who smoke often have to smoke outdoors away from the building entrance. On August 12006 , Carleton University introduced a new policy that prohibits smoking on campus except in 21 Designated Smoking Areas (DSAs). This new policy was drafted in complementing with the Ontario government's Smoke-Free Ontario Act 2005, which prohibits smoking in enclosed workplaces, company vehicles, and enclosed public places (Carleton University 2006).

Behind the construction of risk lies the underlying assumption that society can be free of risks (Fisher \& Poland 1998). This assumption reveals the strong intolerance for the unhealthy or the 'deviant other' as embodiments of risk. Public health risks are seen as a threat to the moral or social order of society. The elimination or removal of risk through practices which target specific spaces and social groups becomes a means of social control and exclusion. This also means that people carry a strong moral responsibility to protect themselves and their neighbourhoods from sources of risk and to exercise 'appropriate caution' or exposure to disease. This risk management becomes a matter of civic duty for health and its contribution to the nation's productivity. Framing certain illnesses 
as 'preventable' highlights the apparent responsibilities of those who become affected (Fischer \& Poland 1998: 196).

Using the case of SARS provides a context in which Armstrong, Fischer and Poland's construction of risk can be analyzed. In 2003 an infectious disease outbreak of Severe Acute Respiratory Syndrome (SARS) emerged in China and moved through East Asia until it eventually arrived in Toronto's Chinese community. The first reported case of SARS on March 9, 2003 was thought to be tuberculosis, however a week and half later the Ontario provincial government declared a health emergency and over 13,000 people were placed under quarantine, for the first time in over 50 years (Naylor 2003; Sanford \& Ali 2005). The public health responses to SARS were heavily criticized for providing conflicting information and relying on traditional quarantine measures to separate the potentially unhealthy from the healthy population (Naylor et al. 2003; Sanford \& Ali 2005). This classification of potentially unhealthy populations from the 'clean' and healthy spaces had a detrimental effect on those groups who had become associated with SARS. The construction of at risk populations during SARS reinforced the process of racializing disease (Sanford \& Ali 2005). It can be argued that SARS was not only a racialized disease in terms of the effects the construction of risk had on the Chinese community, but these also lead to moralized notions of what was considered "clean" by making comparisons to the rest of the healthy majority population. 
In the context of the SARS outbreak, the concept of risk became a collective experience, but not necessarily an equal experience (Sanford \& Ali 2005). At the same time, Toronto residents became responsible for monitoring for personal symptoms, in service of the quest for the maintenance of a healthy population. Such mechanisms are powerful in their maintenance of a generally compliant population, primarily through the instillation of fear of contracting some unknown disease. Simultaneously, risk discourses perpetuate social exclusion through the identification of groups with disease and consequently the construction of the 'other' in space (McGillis Hall et al, 2003). It has been observed that the populations associated with risk most often represent previously marginalized groups who have negligible power over the definingprocess of 'risk groups', responsible for reaffirming their constructed deviance within society. For example, there has been a long history of associating immigrants (perceived of as 'foreign' like the disease for which they are deemed responsible) with disease in Western societies. Craddock (2000) documents the 'metonymy between place and disease' in $19^{\text {th }}$ century San Francisco, where the Chinese community and Chinatown were explicitly scapegoated for the progression of smallpox within the city.

The social exclusion of risk populations has historically been associated with immigration and the perception that the emergence of a new disease was caused by immigrants arriving in Western societies. Similarly to the social exclusion of many members of the Chinese community during the SARS 
outbreak, for smallpox in the $19^{\text {th }}$ century, the city of San Francisco also blamed the disease on the Chinese community (Sanford \& Ali 2005). The construction of risk populations in both the SARS outbreak of 2003 and the $19^{\text {th }}$ century smallpox epidemic also highlights the connection between space and disease. Public health authorities did not explicitly link the Chinese community to the SARS outbreak, however the Chinese community was identified as a site of 'high risk' for infection and therefore the people of that space were associated with the disease. There were reports from Chinese-Canadians indicating that the Chinese community did in fact experience racist comments and moralistic attitudes from the general public during the SARS crisis (Leving \& Guan 2004). Many people from the Chinese community, as in other historical outbreaks, became viewed as the 'diseased others' and were socially outcast from the rest of society.

Research findings suggest that the majority of people received their SARS information from the media, the public health department or their workplace (Cava, Fay, Beanlands, McCay, Wignall 2005). The SARS outbreak also created some skepticism and concerns from the Chinese community on how the situation was handled. Dr. Jian Guan studied the mass hysteria across Canada that the SARS cases in Toronto caused by systematically examining media reports on SARS from March to June 2003 through a content, discourse and visual analysis of Canadian mainstream newspapers and magazines. This analysis of media coverage of the SARS emergency resulted in a public moral panic towards members of the Chinese community in Toronto as well as in other cities across 
Canada. The media content analysis indicated that the SARS virus was constructed using terminology such as "deadly", "mysterious" and "killer", therefore leaving many readers fearing the ramifications of the virus. The media discourse analysis demonstrated how the SARS virus was compared to the 1918 Spanish Flu, which killed over 40 million people. During the early media coverage, "health experts" were quoted in describing SARS as the "Peril from the East" (Leung \& Guan 2004).

During the early media coverage of SARS, patient's names and nationalities were often provided thus exposing the patient's ethnic identity. This was considered contrary to bio-ethics and a poorly managed means by which to gain public control over the SARS virus. It also resulted in the public avoiding and in some cases overtly stating racist remarks to members of the Chinese community and others who were perceived as Chinese. The media images of Chinese faces with masks were exploited by the media and communicated a powerful message to the public that there was a risk of being in contact with any Chinese person, creating an anti-Chinese attitude. The result of the media exploitation created economic hardships for many small business owned by Chinese citizens as well as enduring racist attitudes by others (Leung \& Guan 2004). The image below is taken from the CDC Foundation website. The caption for the SARS image on their website indicates a similar theme to the analysis $\mathrm{Dr}$. Leung conducted on SARS media images during the SARS emergency in Canada (Leung \& Guan 2004). 


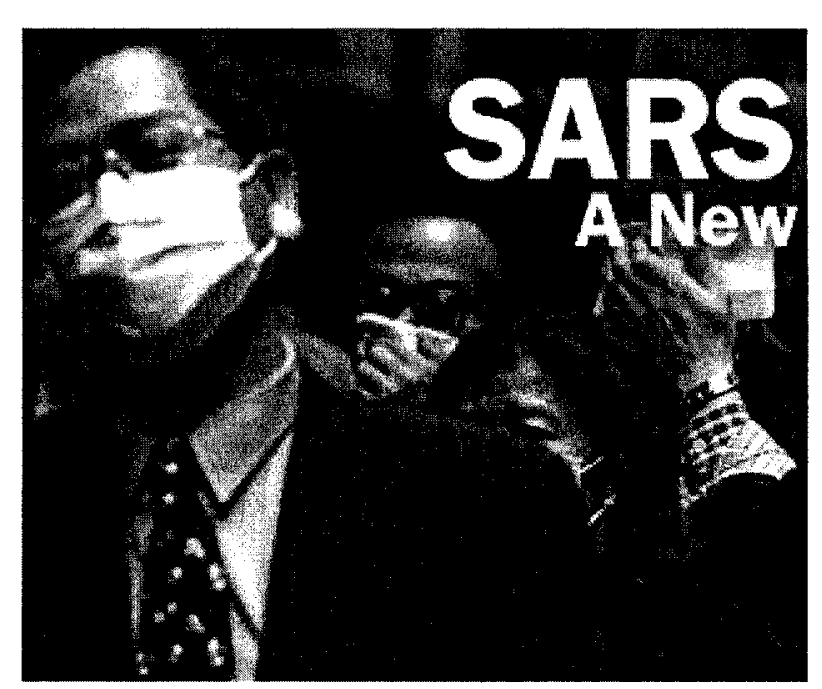

"Severe Acute Respiratory Syndrome (SARS) is a mysterious respiratory illness that sickened more than 8,000 people worldwide, and killed more than 750 , between November 2002 and July 2003. While there is no known SARS transmission anywhere in the world at this time, $C D C$ and its partners continue to monitor the SARS situation globally" (CDC Foundation Website).

While SARS was not explicitly linked to a specific population by public health, it was overtly and tacitly associated with the Chinese community and spatially with Chinatown in Toronto. The identification of sites of 'risk' (in this case of SARS, these sites included China and other areas in Asia) often results in spaces, and consequently people, being associated with disease. Although in Canada the general trend has been that overtly racist stereotypes have been replaced by new, more covertly racialized articulations and attitudes, extreme circumstances such as the outbreak of infectious diseases may serve as the catalyst for the return of more overt forms of racism. Thus, such situations where the infected or those exposed to SARS are separated from the healthy can potentially result in public health functioning as a 'subterfuge for discrimination' (Leung \& Guan 2004). It is evident that racism was experienced by many 
Chinese Canadians in Toronto during the SARS outbreak. For example, there were reports from Chinese-Canadians that many in their community faced daily exposure to racist attitudes, which ranged from people refusing to sit next to them on the public transit system to overt expressions of blame for the SARS outbreak (Leung \& Guan 2004).

The construction of 'risky behaviours' also plays a role in the social construction of identities as well as regulating attitudes around health. People negotiate their 'risky' behaviours according to the context created by social boundaries, and relationships with others and ourselves. Angus Bancroft examines the impact of HIVIAIDS in the context of globalization. Bancroft argues that the spread and impact of HIVIAIDS was closely intertwined with imbalances of power and access to resources among different groups of people in different parts of the world. These global and local inequalities are reproduced in this disease context (Bancroft 2001:89). HIVIAIDS has a significant role in the construction of identities. It has a major significance for gay male identity despite not being exclusive to gay men.

Bancroft's empirical work drawing on interviews conducted in 2000 as a part of a qualitative investigation of health disadvantages in Scotland, highlights the fact that identity is constructed around disease. In this case, injecting-drug users infected with HIV constructed their ability to cope and live with the virus as a "badge of pride", especially when they beat medical odds (Bancroft 2001: 95). 
For gay men the experience of the disease became a communal one and a strong social and cultural signifier of the gay community. However, for the women in the study experiences with HIVIAIDS were quite different. Women did not have similar experiences to gay men nor were they able to draw upon the same social support networks. Bancroft argues that in terms of the impact that HIVIAIDS has on individuals, gender, class and ethnicity all interact. For example, the South African women who publicly admitted that they were HIV positive became ostracized by their communities, and when these women turned to the gay-run support groups for support, they felt out of place and described them as designed and run for middle class white men (Bancroft 2001: 96). "I went to an AIDS support group, but the only people there were rich, gay, white men. They were very polite and kind, but there was no support they could offer me" (Black mother, South Africa, BBC World Service, 22 March 2000 cited in Bancroft 2001:96).

Diseases carry social meanings for people, which extend beyond the physical impact on the body. The virus comes to represent the fears and insecurities within society. Disease represents the fear of spatial violation, the loss of bodily integrity. HIVIAIDS violates the security of the self and becomes a disease by which individuals, communities and larger societies are filtered through social inequalities and differences (Bancroft 2001: 97). The impact on various social groups is also experienced differently. Bancroft states that there is a hierarchy of suffering. In the case of HIVIAIDS, white gay men, being the 
disease's most prominent victims, felt themselves to be the best supported in the study. This hierarchy is maintained and created by "flows of resources, power, knowledge and capital" (Bancroft 2001: 96).

The lived experiences of those impacted by the disease are also not the same. Some individuals or groups of individuals may have different access to resources, and more or less power and control within society. Health inequalities exist both globally and locally and within different communities. The process of globalization affects the most vulnerable or marginalized populations. These populations might be either in a 'developing world' or a 'developed world'. The majority of people with HIVIAIDS within the United States are non-white and blacks and Hispanics, accounting for $51 \%$ of the HIVIAIDS cases in that country (Bancroft 2001: 89). In addition to ethnic and racial differentiation, gender differences are also apparent in both the developing and developed worlds. Women suffering from HIVIAIDS have often been marginalized or even completely ignored. HIVIAIDS education has tended to focus on women as being the potential carriers of this infectious disease or the agents responsible for enforcing safe sex practices with their partners (Bancroft 2001: 94). The level of support for women is also limited; for example, there is an imbalance demonstrated when female sex workers are represented as dangerous to their clients and are seen as a high risk population, but there has been little concern for the women themselves becoming exposed to HIVIAIDS (Bancroft 2001: 94). 
In many cases, marginalized suffers lack the support required and often face social exclusion, this can be observed in both the developed and developing worlds. In South Africa, middle-class white sufferers are able to access treatment and support similar to the resources available in the West. However, in the West, the poor, ethnic minorities, injecting-drug users, and sex workers find themselves facing similar problems of exclusion as those suffering in the developing world. Bancroft argues that the level of exposure to risk and the consequences are not similar everywhere ,but are similar in regard to the divide between "in" and "out" groups in terms of the extent to which risk can be managed or avoided, and its consequences minimzed (Bancroft 2001: 94). HIV/AIDS is increasingly becoming a disease of poverty and its stereotype as a primarily as a middle-class white gay disease is slowly eroding due to the inequalities in health care access and treatment and prevention (Bancroft 2001: 95).

\section{Construction of Diseased Others}

In the construction of risk populations, comparison of the unhealthy population to the healthy population poses the potential threat of marginalization and social exclusion. Said's concept of 'othering', taken from his discourse on Orientalism, provides a framework for analyzing the process of social exclusion. Edward Said argues that Orientalist notions of 'others' have never been more evident than in today's societies (Said 2004). Fears associated with powerful stereotypical representation of 'others' and the moral disgust towards different 
lifestyles can be observed in regard to socially-based reactions surrounding health issues.

For Said the 'West' turned the 'East' into a discourse and a fabrication of constructs. The 'others' were seen as mysterious and dark, reinforcing notions of the West as 'rational' and the East as 'backwards'. Said stated that Orientalism was a "Western style for dominating, restructuring and having authority over the Orient" (Said 1979:3). The orientalizing concepts of the East and the West are a 'fictional construct embroidered with myths and fantasies'. What the West classifies as 'East' is the 'Middle East', and is quite different from the word for 'West' in Arabic (Maghreb) which refers to North Africa, the western part of the Arab world (Shohat \& Stam 1994: 13). The term 'West' also has a long history of ambiguity, which goes back to the West/East division of the Roman Empire. The West was defined as Judeo-Christian and the East as Muslim, Hindu and Buddhist. The final division between these two concepts was the post-war division of Europe into the capitalist West and the communist East. It is clear, then, that politics and power determine the categorization and representation of concepts imposed as identities upon people in societies (Shohat \& Stam 1994).

Orientalism offered a new way to conceptualize the history of or relation between what is called the West and the East. Instead of designating the concepts as neutral scholarly notions, Said argues that Orientalism is a discourse in which the West's Eurocentric view of the Orient is influenced by desire for 
domination of the 'East'. Michel Foucault's proposition that all forms of knowledge are productive of power is used by Said in assessing the implications of the Western construction of the Orient "as an object of knowledge during the period of colonial expansion" (Lewis 1996:16). In accepting knowledge as not being innocent, Said is able to consider how Orientalism, as a representation of the East as different and inferior, legitimized Western intervention and rule. Therefore, representations of the Orient produced by Orientalism are not accurate reflections of a true reality but rather a composite of images, which come to define the nature Orient as "irredeemably different and always inferior to the West" (Lewis 1996).

Orientalism established a set of polarities in which the Orient was characterized as irrational, exotic and erotic, and in which the West was seen as rational, moral, just and Christian. These stereotypes not only misrepresent the Orient, they also misrepresent the West, "obscuring in their flattering visions of European superiority the tension along the lines of gender, class and ethnicity that captured the domestic scene" (Lewis 1996: 17). Orientalist knowledge about the East produced by and for the West came to bypass Oriental sources altogether in a process of legitimization that asserted the power of the West to know, speak for and regulate the Orient better than the Orient could do itself (Said 1979: 67):

As a discipline representing institutionalized Western knowledge of the Orient, Orientalism thus comes to exert a three-way force, on the Orient, on the Orientalist and on the Western 'consumer' of Orientalism...the 
Orient ('out there' to the East) is corrected, even penalized, for lying outside the boundaries of European society, 'our' world: the Orient is thus "Orientalized": a process that not only marks the Orient as the province of the Orientalist but also forces the uninitiated Western reader to accept Orientalist codification....as the true Orient. Truth, in short, becomes a function of learned judgment, not the material itself, which in time seems to owe even its existence to the Orientalist.

The representation of the 'Orient' demonstrated racial categories whose most obvious victims are those whose identity was forged within the colonial 'cauldron': Africans, Asians and indigenous people, as well as those who were displaced by colonialism. The colonized people have generally been ridiculed as 'backwards' in terms of both culture and history because of colonialism. Racial categories are not absolute but rather can vary with time, location and context. However, racist thinking is 'tautological and circular' in the sense that the powerful are right because 'they' are powerful.

Haldrup, Koefoed and Simonsen take Said's concept of Orientalism one step further and argue that 'practical orientalism' occurs in the everyday use of language and that these markers are so unnoticed that these orientalist notions of the 'other' become part of our daily language. Linguistic markers such as 'us' and 'them', 'ours' and 'theirs', 'this country', 'society', 'here' all contain powerful social meaning that are reproduced and naturalized as part of our everyday lives (Haldrup et al. 2006). These linguistic markers are indicators of otherness and lead to Tajfel and Turner's discussion of comparing identities and the biases associated with comparing groups of people. Haldrup, Koefoed and Simonsen argue that, 'the everyday consuming and (re)negotation of orientalism in complex 
ways (re)-produce the discursive system of power and dominance that establish it as a natural, self-evident, (taken-for-granted) global moral orders (Haldrup et al., 2006:175). The stereotypical representation of different social groups becomes apparent in the Chinese community's experience with SARS. During the SARS epidemic many of these stereotypical representations were entrenched with moralist assumptions of the 'unclean diseased' body of the 'others'.

A similar SARS like epidemic occurred in San Francisco in 1900, which fostered similar experiences of discrimination by the Chinese community from the rest of society. The panic and fears around the bubonic plague originated from the fear that a Chinese resident in San Francisco died of the disease, thus causing the city to order immediate quarantine of Chinatown. The majority of the police force was dispatched to Chinatown shortly after to remove all 'whites' from the affected area and allowed no one to enter or leave Chinatown (Shah 2001:120). The Bubonic plague had already devastated major cities in India and China, causing economic hardship on trade ports in Hong Kong and Bombay as well as killing millions of people in the process. However, when a Chinese resident in San Francisco died of what was believed to be the bubonic plague, it was assumed that that the deadly disease was associated with the Chinese community. Thus the contaminated and the uncontaminated would be quarantined together "among racial lines" as it was believed that this would be the most effective public health measure (Shah 2001:121). 
Shah argued that Chinatown was seen as a natural target area since it had been observed as an unsanitary area that would exacerbate the spread of disease. During an epidemic outbreak boundaries are often drawn in order to quarantine, in this case they were drawn on racial lines. The individual who was believed to carry the bubonic plague did not end up dying from the disease but rather had been ill for six months before his death (Shah 2001). In June 1900, the three month quarantine measure was finally lifted off of Chinatown. Judge William Morrow argued that it was "an act based more on discrimination than on maintaining the public's health" (Shah 2001:144). The purpose of quarantine was to isolate those infected from the rest. Morrow believed that it was not appropriate to enact the quarantine on the entire Chinese community, and making Chinese residences more vulnerable to ridicule and social isolation from the rest of society.

In a study on the public's response to SARS in Toronto and the United States, findings suggested that the SARS outbreak had a significant psychological and economic impact in Toronto and Ontario as a whole (Blendon, Benson, DesRoches, Raleigh, Talyor-Clark 2004). The surveys demonstrated that there was mixed feelings about the success of efforts to educate the public about the risk of SARS. Better communication was needed by public health officials, clinicians and the media. These findings suggested that the media coverage of SARS can be a 'double-edged sword'. The media can inform people 
on how a disease is spread and what precautions to take, yet people who live a far distance from the site of the outbreak can overreact by taking unnecessary precautions (Blendon, Benson, DesRoches, Raleigh, Talyor-Clark 2004). What was interesting from this SARS study was the finding that the population in both Toronto and in the United States knew how contagious the disease was, and were prepared to comply with a quarantine or isolation order. This finding suggests that people feel a moral obligation to act in the best interests of society. This is evidence of a how people can internalize compliance and feel obligated in protecting the rest of the community. This demonstrates that moral regulations have the power to govern an individual from a distance.

In the case of SARS, the construction of the 'diseased other' had a negative impact on the Chinese community. Similar to the San Francisco epidemic in 1900, the Chinese community was seen as the cause of infecting the rest of the community. In the case of the San Francisco plague, quarantine measures were overtly based 'among racial lines' (Shah 2001: 121). However, in the case of SARS, the members of the Chinese community were socially isolated and discriminated. In Chapter three, a closer examination of the health care system and the different means of regulating health will be conducted. In many cases not all people receive 'equal' access to health care services. Moral regulations play a vital role in governing certain health issues over others. 


\section{Chapter Three: Regulating Health}

In today's fast-paced society, people have become anxious, fearful and even obsessed with health, disease or the current health 'hot topics' overexposed in the media. Once one of these illnesses crosses over into the human health domain or even threatens human infection, this obsession turns into a mission intent on controlling all relevant illnesses and diseases. Finding the genetic cause or risks that are associated with that disease are puzzles that are often entrusted to a select group of 'experts'. Medical and scientific experts are often highly regarded and hold a significant amount of power in society. In addition to empowering a select group of people with the capacity for and access to knowledge, the 'right to health care' belief fuels and reinforces these experts' role in meeting society's expectations of living a long and healthy life. It is a fact that individuals in Western society do live longer and more pain-free than at any other time (Galor \& Moav 2005). However upon closer examination of the health care system, not all people receive 'equal' access to health resources and health care services. The accessibility of these services still varies dramatically based on geographical location, socioeconomic conditions and the social and physical conditions of the group (Petersen 1994).

The fields of science and medicine construct explanations of health outcomes as neutrally based and non-random. This medical knowledge is perceived by the medical community, as well as the majority of people in society, 
as objective, non-judgmental and free from any moral assumptions. It can however be argued that these scientific explanations do have entrenched moral views embedded within the description of what are considered health 'risks', and this can ultimately have an impact on the people that become affected by illness. When an action is considered 'bad' or 'good' for your health by health experts, these descriptive words are actually morally based. Within many medical descriptions, the personal responsibility for being 'sick' is placed back onto the individual themselves. This chapter will investigate the complex relationship between morality and health, while attempting to demonstrate the moral dichotomies of what is considered 'right and wrong'. Using the works of researchers such as Allan Brandt, Paul Rozin, Deborah Lupton and others, the relationship between health and morality will be deconstructed and illustrated through historical as well as more recent accounts of illness, including AIDS.

Moral assumptions concerning disease are culturally and historically specific; thus, the links between health and morals will be demonstrated within their historical context. The contrast between nineteenth-century views that integrated mind and body, morals and medicine with more modern biomedical reductionism demonstrates that modern views of disease reflect powerful moral views of individual responsibility. These norms and values, central to modern society, are committed to banishing health risks. However, it can be argued that these formulations obscure important social and cultural forces that themselves foster vulnerability to disease (Lupton 1994, Petersen 1994). Some argue then 
that the increasing medicalization of Western society has encouraged moral judgments about health and disease (Mechanic 1997).

The second section of this chapter will explore a variety of particular behaviours associated with moral views of disease. An assessment of the concept of disease will be conducted using specific examples of epidemics and illnesses. I will look particularly at the relative impact of moralization of health behaviours and beliefs. I agree with Howard Leichter with regards to secular morality rising in modern society and how it can lead to an emphasis on "lifestyle" correctness with powerful possibilities for discrimination and stigmatization. Indeed, notions of individual responsibility and control embedded in Western culture and politics may actually work to enhance health disparities (Leichter 2003). The third section will discuss Paul Rozin's analysis of the process of moralization in which morally neutral activity is transformed into one with significant moral weight. Using this framework as well as the concept of moral regulation, an examination of the AIDS epidemic will illustrate the social and psychological process by which behaviour comes to be moralized and discuss the social and personal consequences of moralization for marginalized groups.

\section{The development of health theory}

In many historical societies illness was viewed as one of the many forms of bad luck that required blameworthiness. The biblical link between sin and disease determined that all events on earth were determined by the will of God. 
As such sinners could expect to be punished by illnesses appropriate to their particular form of delinquency, and saints would be healed by miracles. Each of the church's seven deadly sins was conventionally associated with a pathological condition of the body (Thomas 1997:16). Sloth would lead to deadly flesh and palsy, while gluttony would be associated with a large belly, envy with jaundice and fever and wrath with madness. What can be seen during the early nineteenth century is a theory of disease causation invoked by religious beliefs. The epidemics of the bubonic plague that struck England in the sixteenth and seventeenth centuries were simultaneously interpreted as punishments for sin and the product of corrupt air and evil humors (Thomas 1997:18). Penance and prayer were accompanied by public health policies involving quarantine regulations and the cleansing of affected areas.

The increase in secularization and the belief in the biomedical model as the ultimate weapon against disease, illness and abnormalities, stems back to the age of the Enlightenment (Lupton 1994:83). Notions of rationality and individualism, which were major concepts of the Enlightenment era, can still be observed in this 'faith' that is seen today in medicine and science as capable of solving all human problems. Paradoxically, this faith in medical science to provide all of our answers regarding living a healthy life can also become a source for discouragement when one becomes chronically and irremediably ill. Prior to the mid-eighteenth century, numerous theories were given to explain the cause of illnesses and diseases. These theories had obvious moral overtones. 
Diseases were believed to be caused by foul smells and houses being contaminated. These 'corruptions of the air' were apparent indicators that some people, and crowded impoverished places could potentially carry disease or be infected by plagues. On the other hand, the country air where the upper class lived was considered the healthiest place to reside and raise a family (Lupton 1994:81). These dichotomies between country and city living still remain within consciousness today. Moral corruption was viewed as the ultimate cause of illness and disease during this era. It was considered to be the consequences of God's will for those individuals who behaved immorally and therefore deserved to be punished for all to see (Lupton 1994).

The language of the time was certainly capable of distinguishing between physical health and moral purity but in everyday usage the distinctions was often blurred. Infection was conceived of as a form of pollution. Within this framework, some diseases became objects of moral reprobation more readily than others because they were regarded as "unclean", more polluting or repulsive. The more feared diseases were those that transformed the body into something alienating. Leprosy, for example was viewed as a disease related to moral defilement. Lepers were often stigmatized and separated from the rest of society (Thomas 1997).

There was also a strong moral element behind the demand for cleanliness. In the sixteenth and seventeenth centuries it was expected that 
polite persons would wash their hands and face regularly and the invisible parts of the body less often. It was in the late eighteenth and nineteenth centuries that the upper class adopted the habit of regular bathing and disposal of waste products of the body. A growing number of water closets made an appearance and growing inhibitions emerged regarding urinating or spitting in public. It was now considered "uncivilized", therefore, standards of domestic cleanliness rose. Cleanliness, whether it was personal or household, was a sign of hard work, regularity and self discipline. To keep dirt at a distance or work for the elimination of bad smells was a demonstration of moral purity (Thomas 1997: 26-27). This preoccupation with cleanliness in the nineteenth century was often irrelevant to the needs of health and was in fact more related to the values of courtesy, civility and social pretension. These changing moral standards contributed far less to improvements in health and longevity than did improved nutrition and living conditions or the discovery of new drugs. Nevertheless, illness and moral responsibility were intimately linked throughout the nineteenth, and into the early twentieth century.

The emergence of scientific medicine was rooted in the Enlightenment era between the late seventeenth and eighteenth centuries. Many of the medical discourses, ideologies and practices found in today's biomedical models emerged from the ideas produced during this time. An important concept of the Enlightenment era was this faith in society's progression towards an illness-free utopian state, through the use of technology, science and rationality. Medical 
ideologies and discourse rejected religious and superstitious beliefs and were beginning to be perceived as the solution for all humanity's ailments (Lupton 1994). By the late eighteenth century, the medical advice given to the general public focused primarily on controlling one's behaviours. Maintaining a good temper, avoiding excess human pleasures, developing good habits such as diet, regular sleep and exercise were all prescribed as the individual's responsibilities regarding good health. If the individual 'chose' not to regulate her behaviours, then she was blamed if illness occurred (Lupton 1994).

It was during the Enlightenment Era that a rise in the status of the medical professions and of physicians occurred. Prior to the Enlightenment, physicians and surgeons were seen as regular trades people, due to their contact with what were perceived as dangerous and impure substances from the body. They were seen as 'impure and polluted', possessing much less prestige socially and economically than is their current status today (Pouchelle 1990). The role of these medical tradespeople was to investigate and interpret the signs of illness, based on the ill individual's account, and subject to their own distinctive bodily experiences. These personal accounts of one's health experience incorporated a person's emotional, spiritual and physical well-being (Lupton 1994). The ideas of rationality during the Enlightenment years increased the importance placed on scientific principles and greater control over trained medical practitioners also became a regulated affair through formal and institutionalized education. These formalized developments did however result in the improvement of patient's 
recovery rates and therefore further reinforced the trained medical practitioners' role in society (Lupton 1994).

The European states during the nineteenth century were in a time of flux. This was primarily caused by the increased industrialization and urbanization. The concern for sustaining and developing a strong free market economy was reflected in the greater emphasis on social welfare programs, environmental concerns and the emergence of institutionalized hospitals and health care (Lupton 1994). Public health programs focused on hygiene, diet and general health habits became very popular around this time. Up until the end of the eighteenth century, medical practice was primarily concerned more with the health status of the actual individual and how their particular health status had changed. However new ideas of what was considered 'normal' in respect to patients' lifestyle and habits were now being compared to a standard 'normal person' created by the medical profession. Foucault argued that medicine became concerned with how far a patient deviated from that norm and whether the patient could be 'fixed' to meet that norm once again. Patients were now being judged on their actions and behaviours towards remaining healthy and productive citizens. The hospitals' role was now to monitor the ill, classify the illness and maintain information on its patients for future visits or research (Foucault 1975).

The shift from the 'sick' having the responsibility to choose their own practitioner based on their perceived views of that particular doctor's worth, to an 
institutionalized system of regulating formal qualifications and principles, began during the Enlightenment era (Lupton 1994, Thomas 1997). The 'sick' were now being categorized and labeled as 'patients' and the institutionalization of the practitioners' authority was delegated the power of the 'expert' within this formalized relationship. The patients now became passive recipients during consultation regarding their own health. Along with patients' passive role, their behaviours had now also become regulated by the rules of how to conduct themselves and behave within the hospital setting. The morals of the patients were a consideration within some hospitals' rules and some patients would have to adhere to these rules in order to receive health services. Some examples of the hospitals' management rules included: (Oxfordshire Health Archives 2006)

Patients "were to attend prayers, were not to swear or play dice or cards and were to behave decently" (1840)

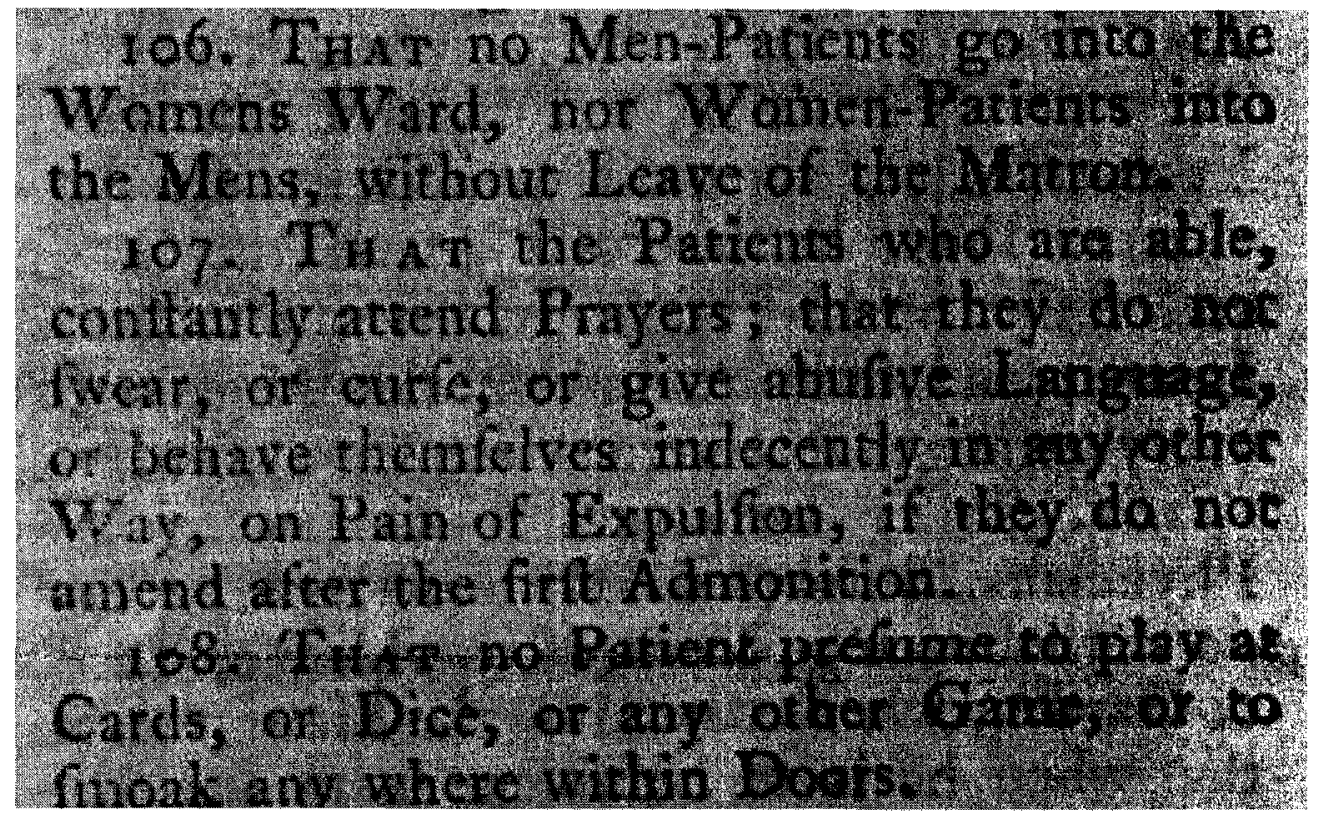

'Resolved that a distinction be made in the sort of meals served up for the Superior \& Inferior Patients ... with respect to the food of the Inferior 
Patients it be such as is suitable to their habits of life [Warneford Committee of Management 1828]

'No Female, except the Mother, Wife, Daughter or Sister, shall visit any Male Patient; and no Male, except the Father, Husband, Son or Brother, shall visit a Female Patient, except by special permission' [Radcliffe Infirmary by-laws 1898]

At the Radcliffe Hospital in England some of the hospital's visitors documented their comments in the Visitor's book, such comments included (Oxfordshire Health Archives 2006):

'I think it very improper to place a Procuress and a Prostitute upon the Beds of the Lichfield Ward which as I am informed was done on the last admission day - ought the feelings of the virtuous to be outraged in this manner? Never were ministerial prudence and pastoral authority better exercised than in excluding their Prostitute Friends who came to visit them'

The idea of a correlation between certain diseases and immorality was widely accepted in the nineteenth century. Venereal diseases were linked to immoral behaviours, masturbation was thought to have caused insanity or "madness" and women were forced to have operations in order to rid them of their "internal sensations" (Shorter 1997).

'Venereal Disease is expressly mentioned as a reason for excluding a Patient ... The effect of allowing females to stay under such disease is to act unjustly by all the virtuous females in the Ward ... It is moreover unchristian, as an offense against the Christian admonition "evil communications corrupt good manners" (Oxfordshire Health Archives 2006)

The victims of cholera received the same harsh treatment that plague victims had received during outbreaks. Similar to other plagues, cholera is easily 
transmitted among people living in unsanitary conditions and was spread through food and water contamination. Very few people during this time had the luxury of sanitation mechanisms. Symptoms of cholera included severe cramps, vomiting, fever, dehydration and eventually death. Cholera spread quickly through impoverished communities, the New York Times in 1866 described it as "the curse of the dirty, the intemperate, and the degraded" (Allen 2001). Victims of tuberculosis, or the "consumption" disease as it was called also received harsh attention. Tuberculosis was a ruthless and chronic disease that caused fatigue, weight loss, fevers, chills and bloody cough. Similar to other illness during this time, it affected people who worked and lived in crowded conditions and suffered from malnutrition, in particular the "urban poor" (Allen 2001). It can be argued that these ideas still remain today, especially in First Nation's communities. Tuberculosis, cholera and other infectious diseases were linked to "immoral" living. The patients who did receive treatment were typically wealthy and were encouraged to take time to rest in the countryside (Allen 2001).

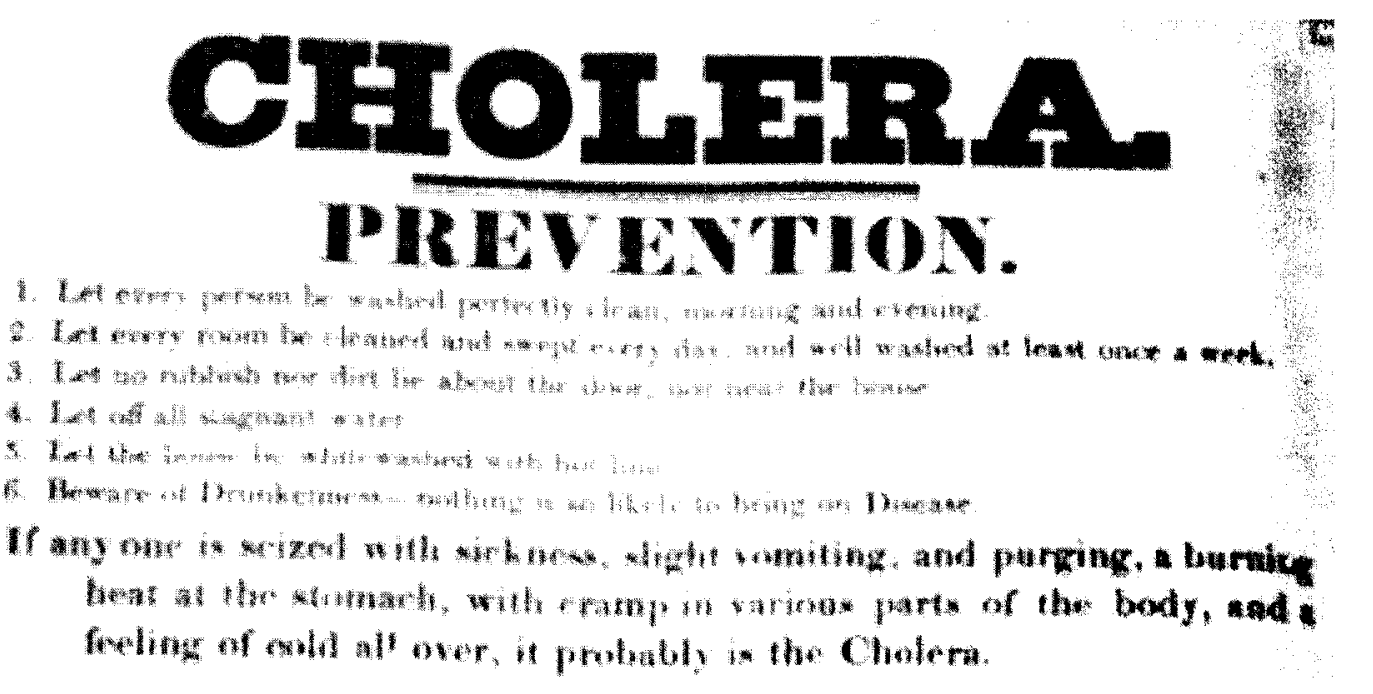


These documentations by both the hospital and its visitors also indicate what Michel Foucault called the clinical gaze or "observing gaze". It was believed that these physicians had the power to see the hidden truth. Foucault sought to investigate the origins of clinical medicine and the eighteenth century movement for the reform of medical institutions. He wanted to analyze how the medical gaze became institutionalized and inscribed in social spaces, and how the new formalized hospital supported this new form of gaze. Doctors acquired their position of power though their ability to observe their patients. This ability was learned through internships, apprenticeships and the knowledge taught by medical schools. Once this power and ability to look with a clinical gaze was acquired, doctors were able to diagnose and communicate their wisdom. This wisdom was and arguably still is not questioned by patients (Foucault 1975).

It presented [the practical knowledges of medicine] as the restitution of an eternal truth in a continuous historical development in which events alone have been of a negative order: oblivion, illusion, concealment. In fact, this way of rewriting history itself evaded a much truer but much more complex history. It masked that other history by assimilating to clinical method all the study of cases, in the old sense of the word; and, therefore, it authorized all subsequent simplifications whereby clinical medicine became simply the examination of the individual (Foucault 1975:57).

The Enlightenment era glorified the clinical gaze by convincing society that clinical wisdom had always existed and that therefore this trust in the medical sciences was justified.

The observing gaze refrains from intervening: it is silent and gestureless. Observation leaves things as they are; there is nothing hidden to it in what is given. The correlative of observation is never the invisible, but always the immediately visible, once one has removed the obstacles erected to reason by theories and to the senses by the imagination. In the clinician's 
catalogue, the purity of the gaze is bound up with a certain silence that enables him to listen. The prolix discourses of systems must be interrupted: 'all theory is always silent or vanishes at the patient's bedside (Foucault 1975:107).

Foucault states that the power of the gaze replaces all other systems of knowledge, including the knowledge that is learnt through medical school.

The clinical gaze is not that of an intellectual eye that is able to perceive the unalterable purity of essences beneath phenomena. It is a gaze of the concrete sensibility, a gaze that travels from body to body, and whose trajectory is situated in the space of sensible manifestation. For the clinic, all truth is sensible truth (Foucault 1975:120)

The power and authority of the medical gaze was also reinforced by the physicians' ability to diagnose the mysteries of disease and provide solutions regarding the cure.

In the depths of its being, disease follows the obscure, but necessary ways of tissue reactivations. But what now becomes of its visible body, that set of phenomena without secrets that makes it entirely legible for the clinician's gaze: that is, recognizable by its signs, but also decipherable in the symptoms whose totality defined its essence without residue (Foucault 1975:159).

Examining the series of different architectural projects at the Hotel-Dieu in 1772, Foucault noticed how hospitals were designed under a system of centralized observation. This was done in order to "avoid undue contact, contagion, physical proximity and overcrowding, while at the same time ensuring ventilation and circulation of air, at once dividing space up and keeping it open, ensuring a surveillance which would be both global and individualising while at the same time carefully separating the individuals under observation" (Foucault 
1980:146). Foucault identifies spaces such as the hospital, prisons and army bases as concrete spaces but also marginal spaces, due to the fact that they do not play a role in most people's everyday lives. These spaces often require a different set of regulated behaviours and practices before one can enter, many of which are not part of our everyday habits. These performances often reinforce the rationalities behind the regulated behaviours (Foucault 1980).

Foucault also argued that the alleged scientific neutrality of modern medical treatment of madness was in fact a cover for efforts to control challenges to a conventional bourgeois morality. It was during Foucault's analysis of mental illnesses that he came to associate nineteenth century medical treatments for "madness" with punishment and the regulation of behaviours. This form of governmentality was presented as objective and neutral scientific explanation but in fact was the product of certain underlying social and ethical commitments. It was through his archival work with nineteenth-century histories that Foucault was able to observe the emergence of this new idea of categorizing the 'mad' as being sick that needed to be 'cured'.

The classic perception of madness that developed during the nineteenth century around mental illness contained underlying moral beliefs. Madness was not necessarily seen as an illness or disease that could be treated. However, Foucault suggests that the idea of being 'cured' at that time was not a development within medical thinking but rather developed from moral perceptions and therapeutics of the body. The Madness disease was viewed through this 
moral lens since it was situated between the body and soul. Foucault lists these cures and their philosophies. 1) Consolidation. Madness has elements of secret weakness, a lack of resistance. A force needs to be found in nature to reinforce nature. 2) Purification. Madness elicits a series of therapeutics that are intended to purify. The ideal is total purification. 3) Immersion. Two themes are present; ablution (washing) and immersion, which modify liquids and solids. Plunging madmen into water offers a chance to return to purity. 4) Regulation of movement (Foucault 1965:38).

These classic pre-eenlightenment cures were viewed as helping both the affected mind and the body of the individual. Foucault observed however a difference between these "cures" and nineteenth century techniques which centered on the moral improvement of the sick mad person and his/her abnormal or "bad" behaviour. A 'normal' person in society would obey his or her conscience and immoral behaviour provoked by madness would be punished by confinement or surgery. For Foucault, the idea behind the illness of madness was that it was in fact a moral evil, arguing that an attempt to use guilt as a psychological treatment would be a means of morally judging the individual (Foucault 1965).

During the late $17^{\text {th }}$ century, with the invention of the microscope, a new acceptance of the idea that diseases were caused by microorganisms that were invisible to the human eye became widely accepted (Rosenberg 1997). The discovery that bacteria can cause illnesses became valued in the context of the 
progress of scientific medicine, as laboratory research rather than subjective observations of patients took centre-stage (Rosenberg 1997). This change in perception about what causes disease was, and arguably still is, a powerful and influential statement that can reflect powerful political moral ideologies about risk, moral responsibilities and illness.

The germ theory developed by Robert Kock was developed shortly after he uncovered the turbercle bacillus, in 1882 (Brandt 1997). It was not until this discovery that the stereotypes that tuberculosis was caused by weakness or moral decay began to disappear. From this discovery, Koch concluded that diseases in general were the direct result of a single organism or bacteria. This idea of "postulates" both revolutionized and idealized medical sciences. However, despite the fact that germ theory did provide a more in-depth understanding of how some diseases were caused, it too was challenged. Researchers quickly realized that it was possible for individuals to be infected with the bacteria but not develop the full effects of the disease. Such medical investigation demonstrated how science could not provide complete reasoning for the cause of all disease. Despite this argument, the search for other types of scientific reasoning, to explain other diseases and illnesses continued, and often ignored other external social factors that could have also contributed to a person's well-being. As Brandt states, scientists were "losing the perspective on the "whole" patient" (Brandt 1997:56). 
The death rate due to infectious diseases did in fact decrease during the early twentieth century and this was often attributed to the germ theory. However some researchers remain skeptical and argue that most data that suggests this improvement in population health was mounting before the germ theory arose. Factors such as changes in sanitation, nutrition, and rate of infant mortality, all led to changes in the number of infectious outbreaks (Brandt 1997). Regardless of the anomalies present in this new paradigm shift, the germ theory had an important de-moralizing effect. Through the biomedical model, disease was now viewed as "random", secular and scientific. It was no longer reflective of personal attributes, behaviours or responsibilities of the individual, as religious and medical theories once claimed. "Disease implied a lack of volition, or, at least, a failure of individual agency" (Brandt 1997: 57).

As a result of medical interventions a new era of rising status and authority for the medical professional arose. The "miracles" of modern medicine performed by doctors in sophisticated hospitals has brought a new respect and affirmation to a profession that only a century earlier had been little more than a competitive trade, and wherein it was difficult to distinguish among a variety of medical sects, healers and "quacks" (Brandt 1997:58). By the early twentieth century the profession had been able to consolidate its authority and power in large measure as a result of the rise of the germ theory. During the course of the twentieth century, with the chronic disease shift, flaws in the 'magic bullet' theory became apparent however. For unrelenting problems such as cancers, heart disease and 
stroke, these were diseases for which it was impossible to identify a single cause or solution. Even in the case of infectious diseases, treatments and therapies often became ineffective due to organisms becoming resistant (Brandt 1997). It was also apparent that certain populations within society were more susceptible to diseases as a result of socioeconomic factors, geography or social and physical environment; other non-medical factors do have an impact on the status of an individual's or community's health.

Implicit in this shift from infectious disease theories to issues surrounding chronic diseases, and an arguable return to incorporate infectious disease theories, is the idea that infectious disease may be perceived to be the result of external forces and seen as a "visitation". Current beliefs regarding chronic disease focus on the idea that disease is no longer caught but rather "acquired" and originated within the body (Brandt 1997:59). The idea that an individual is responsible for their own health outcome by avoiding risky behaviors are more apparent in today's society. But just as the germ theory contained powerful cultural norms regarding the meaning and significance of disease, so do the new health theories which have in turn emphasized statistically configured "risk factors". New questions around responsibility for disease and its prevention have emerged and few could now disagree that disease prevention and health promotion have become creditable goals. The goals of health and longevity have come to rest firmly within public health discourse. 
The idea of an individual moral obligation to preserve one's health also came to be considered a public duty. According to this perspective, chronic diseases depend directly on individual behaviour and habits. Individuals could no longer rely solely on public health interventions, the activities of the medical profession or the health care delivery system to solve the problems of disease. The quest for health would now be carried out by the individual. The new epidemiological studies on chronic diseases demonstrated that there was a possibility of controlling one's health, and disease would no longer be viewed as stemming from random events. An effect of this can be seen in the first boom in physical exercise during the 1970 s and 1980 s, which constituted a powerful shift in cultural values as well as actual behaviours (Brandt 1997:.65).

Exercise became yet another aspect of the "medicalization" of Western culture in which doctors played the role of the health monitor. This fitness revolution did not focus on competitive or team sport, the challenge was within the individual and the goal was to win out over the uncertainties of the body. Exercise, as well as many other aspects of people's daily lives required selfregulation. Failure to take appropriate precautions and enact behaviours against specific risks and individual control was to be combated with self discipline, and the failure to do this was seen as intrinsic and moral (Brandt 1997:64). This idea that individuals can and should exercise control over their health habits and live a good clean life has formed the basis of religious as well as medical ideals of disease. Throughout history, illness was viewed as the physical price of 
sinfulness (Lupton 1999). However the irony is that the process of disease is so complex that the discussion of the "cause" necessarily becomes a socially constructed, and often a controversial debate.

Identifying individual behaviour as the primary health risk factor, even through the use of epidemiologic data, neglects the fact that behaviour itself is, at least arguably, beyond the scope of individual agency. Such "bad behaviours" as cigarette smoking are part of a sociocultural phenomenon, not merely individual or necessarily rational choices (Brandt 1997:68). Nevertheless, individuals who "take risks" are considered ignorant and self-destructive. Identifying disease as a voluntary process demonstrates the cultural imperative for individual control, the logic being that if disease can be avoided by carefully following a set of predescribed behaviours, then individuals can take control over their bodies and their lives. This logical reasoning becomes very narrowly focused. The social context of health is not reflected in the majority of modern health discourses. But individuals live in a context of a group with specific structures, cultures and patterns of valued activities (Mechanic 1997:80).

\section{Morality and Health in today's society}

Contemporary Western medicine is often directed towards controlling the body and mind and as a result emphasizes regulating behaviour. Within medical discourse and ideologies, binary oppositions construct medical explanations, 
patients' experiences and societal views on health issues. The most apparent dualism is that of the mind and body; others include reason and emotions, objective and subjective, adult and child, male and female, purity and uncleanliness: "Sickness is a threat to rationality for it threatens social life and erodes self control" (Lupton 1995). As a result of this binary thinking, some argue that illness and disease are also fundamentally different. Illness is considered a social, lived experience of symptoms and suffering, which are part of the human experience. Part of this human experience is to take steps toward avoiding illnesses.

Both the definition of illness and of disease are influenced by social, historical and political context. And this, despite the belief that modern medicine is 'objective' and 'rational', is free from any moral judgment. The language used within the biomedical model provides powerful examples around moral ideals. Powerful descriptive words such as 'bad', 'sick and 'good' are examples of these moral beliefs surrounding the responsibility of preserving one's own health, regardless of any other external factors. These moral beliefs about health and illness become even more powerful and apparent when attempts are made to provide rational explanations for severe illnesses and diseases. This 'blaming' is not a new concept. Risse explains that during the cholera epidemic in the United States in the 1830's, the victims, who mostly came from the poorer classes, were blamed for the spread of the disease. They were 'guilty' of weakening their 
bodies by engaging in poor behaviours and pleasures and ignoring the Sabbath. They were seen as being paid back for their sins (Lupton 1995).

In today's society, the focus on individuals' responsibilities for maintaining their own health still evokes a strong response. This emphasis on certain lifestyles and lifestyle 'choices' contains notions of avoiding 'risky' behaviours, such as self-indulgence and the lack of discipline. Alternative lifestyle choices are viewed as being the reason why people become ill with diseases such as heart disease, diabetes, lung cancer and liver disease. These diseases are all connected to habits and behaviours which concern diet, tobacco and alcohol consumption (Lupton 1995, 1999). Lupton argues that all of these habits and behaviours are viewed through a moral lens and are considered socially deviant. People who choose alternative lifestyles are put in a position wherein they have to justify themselves and declare that they have avoided all risky behaviour before becoming ill. In the case of AIDS, the media created an image that people who contracted the AIDS virus were 'guilty' of homosexual activities or injecteddrug use. There were some 'rare' cases where 'innocent' victims of blood transfusions or of, say, a bad relationship did contract the disease, but these were seen as exceptional (Lupton 1994, Myrick 2003). There have also been reports of patients being seen as less deserving of medical treatment for smoking related diseases. Some doctors, for example, will screen out patients based on their smoking habits. 
"More and more doctors are turning them away or knocking them down their waiting lists -- whether patients know that's the reason or not... GPs who won't take smokers as patients. Surgeons who demand obese patients lose weight before they'll operate, or tell them to find another doctor. Transplant teams who turn drinkers down flat. Doctors say their decisions make sense: why spend thousands of dollars on futile procedures? Or the decision is the product of frustration: why not make patients accountable for their vices? Others call it simple discrimination. But in a health system with more patients than doctors can treat, where doctors have discretion over whom they'll take on, some say it's inevitable that problem patients will get shunted aside in favour of healthier, less labour-intensive cases" (Macleans April 18, 2006).

Despite the fact that the goal of universal health care in Canada in terms of access is supposed to be equality of access for all, some doctors believe that "lifestyle-induced problems" make some patients less equal than others. Maclean's interviewed doctors across Canada and many of these indeed indicated that they knew of colleagues who would not take "unhealthy patients" such as smokers, drinkers and people who were over-weight "because caring for them would be too complicated, and too much of a burden for their already overcrowded practices" (Macleans April 18, 2006). GP Fredrick Ross stated that he no longer sees patients if they continue to smoke: "I said, this is stupid. I told my patients, you have three months to quit or I am going to ask you to find another doctor," recalls Ross, a genial man. "I said, your smoking is impeding my progress in treating you" (Macleans April 18, 2006). One patient did in fact challenge Dr Ross on the basis of human rights; however the case was thrown out. As one doctor summarized the situation, "the idea that smoking or drinking or excess weight impacts on your health care is just the way the world is" (Macleans April 18, 2006). 


\section{Governing Morals}

In Alan Hunt's book “Governing Moral's: A Social History of Moral Regulation" he addresses moral regulation as a practice of governing the conduct of individuals. Hunt defines moral regulation as "a process in which moral discourses, techniques and practices make up the primary field of contestation" (Hunt 1999:8). It is important to understand the relationship between moralization and political technologies. These moral regulation projects are a form of politics in which people such as health experts can problematize the values and behaviours of individuals and groups, therefore ultimately legitimizing the imposition of regulations on them. "The importance of moral regulation stems from the scope it provides for a variety of different social forces to articulate projects outside the mainstream of official politics and State institutions. Sometimes so successfully that these projects get forced upon mainstream political parties and the State" (Hunt 1999:2).

The politics of moral regulation has become more apparent over the course of the last few decades. Hunt states that the best example of moral regulation both historically and today would be around the issue of consumption. Health discourse plays a vital role in regulating consumption and transferring health care responsibilities onto the individual. In Hunt's comparative analysis of moral reform movements in different historical and social contexts, he demonstrates that there has been a shift from a negative or coercive form of selfcontrol to a more positive concern with self-formulation (Hunt 1999). Throughout 
the different forms of governing, a mixture of "governing others" and "governing the self' takes place in regulating behaviour. However, despite the different forums of governing individual's conduct, Hunt states that all practices of governing involve some element of moral regulation. He also goes on to state that "moral regulation involves the deployment of distinctively moral discourses which construct a moralized subject and an object or target which is acted upon by means of moralizing practices (Hunt, 1999:6).

The moral dimension within the concept of moral regulation is not the target themselves but the linkage between the subject, object, knowledge, practices and outcomes. Hunt explains through an example on child-rearing, the moral framework of a regulation consists of:

- A moralized subject (i.e. parents);

- A moralized object (The child);

- Knowledge (Informal or expert);

- A discourse within which the knowledge is given a normative content (parents should monitor children's activities);

- A set of practices (potty training, etc.);

- A 'harm' to be avoided or overcome (poorly socialized children)

In Hunt's discussion on social movement he explores the way in which laws (formal and informal) become part of the process of moral reform. Hunt shows also that both law and propaganda contribute to the attempt to regulate. For example, modern self-help discourse is a mean of internalized moral regulation. Moralizing discourses are often linked to other discursive components such as individual and population health. Moral regulation therefore is a "discrete make of regulation existing alongside and interacting with political and economic 
modes of regulation" (Hunt 1999:17). Moral reform movements today are located in the context of self-help movements (Hunt 1999:27). Hunt concludes by stating there are different modes or ways of governing the self and others.

Similar to Hunt's analysis of social reform movements, Valverde's discussion of social reform movements in Canada also incorporates ideas about moral regulation. Valverde analyzes the process of 'nation-building and the way in which Canadians have developed their national identity through 'moral reform'. In order to study moral reform at the beginning of the $20^{\text {th }}$ century Valverde focused her analysis on the social purity movement (Valverde 1991:17). "The social purity movement was a large network of organizations and individuals mostly church people, educators, doctors and those we would now describe as community or social workers, who engaged in a sporadic but vigorous campaign to "raise the moral tone" of Canadian society and in particular of urban workingclass communities" (Valverde 1991:17)

The aim of this campaign was to educate the next generation of citizens in developing 'civilized 'habits around cleanliness, sex and moral aspects of social life. Valverde argues that the social purity movement was a part of a wider movement that included socio-economic reform (Valverde 1991:19). Sexual desires were an important topic in the social purity movement, especially in the context of public health. These messages were often conveyed through the production of books, lectures and pamphlets. Sexual habits were targeted as a 
means of re-moralizing the individual and the national identity. Valverde defines these mechanisms of regulation as "positive" measures, not because of the actual contest, but because these pamphlets discussed how people ought to behave, act, speak and think. These measures were not aimed at mere prohibition or 'negative' regulations (Valverde 1991:23). For example, Valverde examines the Methodist church's sex education for boys, arguing that this moral project was aimed at "character-building'. The State role in the purity movement was viewed as being neutral.

The only way in which the State can make its citizens internalize certain values is through the co-operation of the family and voluntary sector. Valverde notes that many voluntary organizations were concerned about nation-building through strengthening the family, church and nation (Valverde 1991:26). Several desires were perceived as the most threatening force to the nation's 'moralfabric' and to civilization. Valverde concludes stating that the social purity movement was concerned about urban vice, however "its real aim was not so much to suppress as to re-create and re-moralize not only deviants from its norms but, increasingly, the population of Canada as a whole. This was a project the state could not possibly have carried out; voluntary organizations played the starring role in the campaign to reconstruct the inner selves and in particular the sexual/moral identity of Canadians" (Valverde 1991:32). Therefore, governing citizens through moral regulations required the participation and acceptance of the family and community. 


\section{Moralization}

The process of moralization described by Rozin is a particularly important framework for analysis in the attempt to understand how health and morality are linked. This process is also relevant to the understanding of social attitudes and responses to health issues and disease outbreaks. This process of moralization depends on a multitude of cultural, political, economic and spatial factors. The AIDS "epidemic" is a prime example of a modern illness being socially constructed through a moral framework. A deconstruction of AIDS reveals the moral assumptions of risk, individual responsibilities, poverty, and stigmatization of the victims. This process of constructing disease allows the healthy population to disassociate themselves from the sick and often impoverished victims of the disease. Therefore, this social construction has an impact on the individual care of those who are sick and also impacts on broader social and political health policies (Rozin 1997).

The process of moralization is particularly relevant to the understanding of attitudes towards health and illness. Moralization is the process through which preferences are converted into values, both in individual lives and at the level of culture. Moralization is often linked to health concerns, including addiction. It is significant because moralized entities are more likely to receive attention from governments and institutions, to encourage supportive scientific research, to license censure, to become internalized, to show enhanced parent-to-child transmission of attitudes, to motivate the search by individuals for supporting reasons, and, in at least some cases, to recruit the emotion of disgust. Moralization seems to be promoted in predominantly Protestant cultures and if the entity is associated with stigmatized groups or harmful to children (Rozin 1997:380). 
Moral values are often internalized and become part of self identity, of our preferences and our behaviour. An object or activity that is aligned with one's moral views may be more acceptable and enjoyable than one that does not align. A culture-wide moralization of a particular entity would usually come about as a result of the growth of a large or politically powerful collection of individuals who accept and promote such moralization. Once the process of moralization has occurred in a powerful or influential part of the population, the forces of government and major institutions align with it, therefore reinforcing and furthering the moralization of a particular illness. This can be seen in people's willingness to accept limits on cigarette advertising without evidence that it is effective in discouraging smoking (Rozin 1997:381). This can be observed also with by-laws that have been passed forbidding moralized activities like smoking in public places and accompanying penalties for violations.

At the informal, societal level, beliefs about health practices demonstrate the link between moral positions and health movements. They thus reinforce the notion that morality does in fact contribute to the commitment required for a successful health movement. The AIDS "epidemic" is a prime example of a modern illness being socially constructed through a moral framework. The deconstruction of AIDS reveals the moral assumptions of risk, individual responsibilities, poverty, and stigmatization of the victims. This process of constructing disease allows the healthy population to disassociate themselves from the sick and often impoverished victims of the disease. This disassociate 
will in turn, have an impact on the individual care of those who are sick and on broad social and political health policies (Brandt and Rozin 1997, Lupton 1994).

AIDS is an example of a health issue that has highlighted the moral judgments and impacts of a disease. This epidemic identifies the important relationship between social and cultural understandings of disease and the moral impact on people affected with AIDS. There are beliefs that suggest that AIDS is caused by immorality itself and that those who behave morally, according to this reasoning, have nothing to fear in the context of this epidemic. However, this logic is flawed by the fact that there are numerous cases in which AIDS can be contracted by means other than sexual. Others believe that there should exist the assumption that everyone is at risk of disease and that, via this reasoning, a caring and compassionate environment would emerge due to the fact that everyone assumes the risk and responsibility connected to this epidemic (Lupton 1994, Brandt 1997).

It has to be recognized that the people who are at greatest risk of infection, disease and death often come from socially marginalized and morally stigmatized populations. In the case of AIDS, the subcultures associated with AIDS were the homosexual community and the illicit intravenous drug using community, so these bore the brunt of the associated stigmatization and were assumed to be responsible for the cause of the epidemic (Lupton 1994, Brandt 1997, Myrick 2003). This epidemic has exposed how powerfully moral notions 
continue to influence not only what a disease is and what we do about it, but what a disease means. Some of the theories used to construct the AIDS epidemic have proven the importance of certain norms and moral beliefs. Within these theories, certain behaviours, choices and lifestyles were viewed as immoral and initiatives were put in place to combat immoral behaviour, including safer sex techniques, widespread distribution of condoms and sterile injection equipment.

A recent Canadian court case provides a good example of how systemic discrimination towards HIV positive individuals exists within society. On August 31 2004, the Federal Court granted an HIV positive woman's application for judicial review of a decision already made by the Immigration and Refugee Board. Jo, a 33 year old Nigerian woman, claimed refugee status based on the fear of persecution in her country and due to her claim of being domestically abused. She argued that the discovery that she was HIV positive once in Canada, would exacerbate the discrimination she faced in her country of origin at a systemic level. According to the Immigration and Refugee Board there was not credible evidence that she would be denied health care in Nigeria, or employment, or that she would be ostracized by her family and community. However the Federal Court found that the Immigration and Refugee Board ignored important documentation and that the Board was obligated to communicate how it came to its ruling. The issue was whether the Immigration and Refugee Board erred by ignoring documentation that proved that people 
living with HIVIAIDS in Nigeria feared persecution based on their being infected. The court ordered that a new panel re-examine the file in light of the fact that there was evidence of discrimination as faced by HIV positive people in Nigeria (Mysko 2004: 53).

The process by which the meanings of AIDS changed so substantially reveals fundamental social perceptions and moral assumptions about the nature of the epidemic. The calls for isolation and quarantine that characterized the early years of the epidemic diminished as the perception of "social quarantine" arose (Brant and Rozin 1997). According to this view of the epidemic, the disease was generally confined to the deviant and the criminal and in some instances to their sexual and needle-sharing associates. Brandt and Rozin argue that these constructions of AIDS are deeply held moral convictions about the nature of risk and the responsibility for disease. This has also occurred with other diseases at other times. Cultural beliefs about disease often reveal society's most basic moral beliefs and practices. These meanings and moral configurations, in turn, have a dramatic impact on both the care of those who are sick and on broader social and political policies. Moral beliefs and convention typically have a material impact on patterns of disease, clinical care and the experience of illness (Brant and Rozin 1997).

Brandt investigates changes in perception regarding what causes disease, the nature of risk, behaviour and responsibilities over the past century in the 
United States. Brandt argues that perceptions around disease and illness are in fact powerful moral beliefs that can implicitly and explicitly affect the social behaviours. Through the social interaction between the healthy population and the "sick" can occur at a more formal and organizational level. For example, people receiving different access to health programs and delivery, reflects powerful political ideologies about risk, responsibilities and illness issues (Brant 1997).

The majority of the explanatory models of disease within society before the late nineteenth century were often based on religious reasoning and justification. This religious reasoning is indicative of the fact that in times of sudden onset of disastrous widespread disease, there was recognition of the lack of human control and subsequent intervention (Brandt 1997:54). Throughout most of the nineteenth century, physicians and public health officials believed in a medical theory that emphasized familial hereditary susceptibility to different types of disease. This theory emerged from the observations that certain people in the population died while others in the same geographic area were spared. This often reinforced the idea of the "worthy" poor, who were spared from the evil disease.

\section{Canadian Public Health}

The Spanish flu was and still is one of the deadliest infectious plagues in human history. The pandemic was estimated to have infected $50 \%$ of the world's 
population, with over 50 million people dying from the flu's symptoms (Palmer 2004). Spanish influenza would attack suddenly and often killed its victims within days of showing symptoms. In the early stages of the flu, victims would show signs of blue tint to their face, and cough up blood due to severe lung problems. In the later stages, the virus would cause uncontrollable hemorrhaging that filled the lungs, and victims would literally drown in their body fluids (Palmer 2004). In the United States more than 600,000 people died; in England 200,000 died and an estimated 17 million died in India. In Canada 30,000 people were killed by the flu and some northern Inuit communities were almost completely wiped out (Palmer 2004). Many countries, including the United Kingdom, experienced more than one wave of the infectious disease (Palmer 2004). The first official record of the flu was in May 1918 in an American military establishment in Spain (Palmer 2004). The flu quickly spread to other military trenches, then to cities and smaller rural communities. It was believed that the close proximities of the military quarters, the movement of the troops in Europe and the living conditions in highly populated urban cities, accelerated the initial spread of the disease.

Many efforts were made to control the spread of the Spanish flu. These efforts included promotion of personal hygiene and disinfectants, prevention of large public gatherings and the enforcement of isolation. During this time, some cities in the United States even fined or incarcerated "open-faced sneezers" for risking the health of the public (Palmer 2004). Many social institutions were closed and some places were even quarantined albeit with different levels of 
success. These quarantine laws made it illegal for someone under quarantine to step outside their residence (Kreiser 2006). Quarantine measures were seen as necessary means in order to benefit the greater population, even though it infringed upon the personal rights and freedoms of the individuals that were viewed as 'threats'. However, it has been argued that the quarantine measure during the Spanish flu were not effective. If the flu had been a smaller outbreak and could be easily contained, the quarantine measures may have been necessary to protect the larger population. In this case, these quarantine measures did not contain the spread of the virus and caused more harm than good (Kreiser 2006).

In the case of the Spanish flu, mass quarantine of healthy citizens who may have been exposed to the virus did not work to contain and control the spread of the flu. In many instances discrimination towards immigrants, lower class and ethnic and racial minorities occurred during the implementation of quarantine measures (Kreiser 2006). These healthy citizens were stigmatized and viewed as the dangerous 'diseased' others. The enforcement of the quarantine measures was conduced by the military or police. This often caused social and moral panic throughout the communities. In many cases, people who were sick and would have sought out treatment would often flee or escape the military enforced quarantine and cause the disease to spread further (Kreiser 2006). With the combination of the lack of medicine, health resources and the militarized mass quarantine measures, the Spanish flu plagued most of the 
world. Quarantine measures are still used today; however, it is believed that people are responsible for the prevention and maintenance of their health.

\section{Canadian Public Health Approach}

The new public health governance highlights that it is the individual that is responsible for the maintenance of good health and that the state does not have as large a role in its citizen's good health. The individual conforms to the governance ideologies and reduces the responsibilities of the state. It becomes an achievement for an individual to express their virtue of self-control and discipline, especially for others to see and reinforce this moral ideal. Therefore, Petersen and Lupton view the "healthy individual" as the moralizing framework used in the new public health governance and ideologies (Petersen and Lupton 1996). It is in the construction of such a governing framework that Petersen and Lupton argue that the "healthy body" ideal is becoming a means by which an individual measures their own moral worth. They argue that this narrow focus on health can become a means of stigmatizing others who do not fit into the mold and becomes a myth that public health is fair and equal for all (Petersen \& Lupton 1996).

The history of public health in Canada was strongly influenced by the United Kingdom. There have been three major phases in Canadian public health. The first phase included the early implementation of public health measures 
such as sanitation, public health nursing, and inspection. The second phase which included the enactment of universal health care coverage; and a third phase included the introduction of government sponsored health promotion programs. Health research suggests that a fourth stage is emerging, which focuses research on health inequalities. In 1848, the first Public Health Act in Canada became law. Early public health measures were concerned with controlling recurrent disease outbreaks such as cholera. Nineteenth century health policies focused on clean water policies in attempts to improve the health status (Fidler 2004).

The second major phase in Canada was the introduction of universal health coverage and services. The Universal Health coverage was based on the British health model and the fact that sanitation and hygiene measures were not sufficient to control the infant mortality rate in England. In Canada, Medicare was enacted in 1968 in attempt to control widespread illness after World War II (Fidler 2004). The third stage in Canadian Public Health policy was heavily influenced by the Lalonde Report (1974). This report contributed to the development of health promotion in Canada. The Lalonde Report recommended that the government policy be extended beyond universal medical care to encourage people to assume more responsibilities for their own health. It was recommended that government policies balance both medical care and health promotion programs in order to improve population health. This report as well as the Epp Report (1986) "Achieving Health for All: A Framework for Health Promotion" 
influenced this new phase in public health in Canada. Health Promotion literature outlined 12 determinants of health including social status, social support networks, education, employment and working conditions, socioeconomic environments, physical environments, personal health practices, healthy child development, biology and genetic endowment, health service, gender and culture (Fidler 2004). Health promotion required the advocacy of health workers to help in improving health of the population.

Health discourse identifies the fact that the level of health of a population is affected by external non-health factors. For example, early health research by Edwin Chadwick on child mortality indicated that the level of child mortality in 1842 can be correlated with the level of their father's income (Marmor \& Barer 1994). Canadian researchers Theodore Marmor and Morris Barer edited a book entitled "Why Are Some People Healthy and Others Not?" which focuses on the inequalities in health (Marmor \& Barer 1994). Using population-based evidence they have attempted to understand how different factor influence health. The research demonstrated that social environments have a "far stronger" impact on health than individual behaviours (Marmor \& Barer 1994). The limitation of the Health promotion literature is that social environments are recognized as a determinant of health, but there is little investigation of the impact of these contexts or any effort to investigate the correlation in detail. Research on inequalities in health has attempted to examine the impact of health determinants over large-scale population and has collected evidence that indicates that the 
physical environment and genetics are less critical than the social environment over the course of people's lifetime. Canadian and other researchers on inequalities in health have attempted to investigate factors, such as lack of control over work and how these contribute to ill health (Marmor \& Barer 1994).

Throughout history public health policy was mainly concerned with biological hygiene of societal spaces and these policies were highly influenced by scientific research. However, it is argued that one single scientific explanation cannot demonstrate the realities of health in society. These positivistic policies perceived the public health as the individual's health, separate from the whole of society (Lupton 1996). Previous public health polices focused around biological hygiene and recent public health approaches are tailored around individualistic health promotion, such as self-help diets. These modern public health approaches do not consider social and economic relationships, new forms of inequalities, exclusion and the marginalization of social groups (Lupton 1996). Social, economic, cultural and political realities need to be understood in order to understand public health and develop public health policies. Throughout the different stages of Public Health policy in Canada, it is apparent that different concepts of health contribute to the formation of different health policy frameworks.

Since the advent of the SARS emergency and the public's panic around a potential Avian flu pandemic, the Canadian government has funded the 
development of domestic pandemic preparedness strategies and emergency capacity measures. In collaboration with the provinces and territories, the Canadian federal government has developed a Canadian Pandemic Influenza Plan that maps out how Canada will prepare for and respond to a pandemic influenza outbreak. The Public Health Agency of Canada was created in response to the public's concerns around the Canadian government's response to any potential threats. The Canadian government budgeted 1 billion dollars over five years to improve Canada's pandemic preparedness. $\$ 600$ million was given to the Public Health Agency of Canada (\$367 million), the Canadian Food Inspection Agency ( $\$ 195$ million), Health Canada ( $\$ 16.5$ million) and the Canadian Institutes of Health Research ( $\$ 21.5$ million) for a variety of pandemic preparedness activities (CBC 2005).

The objectives of the Canadian influenza pandemic preparedness plan are to respond and minimize serious illness and overall deaths, as well as minimize any "social disruption" among Canadians (Health Canada 2006). Health Canada is also responsible for surveillance and response to infectious diseases that have a national impact, population health, and vaccine regulation. Some key parts of the plan include (Health Canada 2006):

- Contracting with a Canadian pharmaceutical company to ensure that large amounts of vaccine are made as quickly as possible.

- A national stockpile of anti-viral drugs. The stockpile will be used to treat identified priority groups.

- The National Emergency Stockpile System (NESS), which contains everything that you would expect to find in a hospital, from beds and blankets to a supply of pharmaceuticals. 
- A real-time alert system for serious respiratory illnesses (SRIs), including SARS and avian influenza, to ensure timely dissemination of information to the provinces and territories.

- A hospital-based surveillance system to detect cases and clusters of severe or emerging respiratory infections.

- Quarantine services at major Canadian international airports. Quarantine officers provide health assessments for international travellers who have signs of illness.

The plan also includes a four-pronged approach, in the case there was a pandemic (Health Canada 2006). This plan consists of:

$>$ Prevention activities, such as annual immunization programs and the establishment of an infrastructure for manufacturing sufficient vaccines to protect all Canadians at the time of a pandemic.

$>$ Preparedness activities, including simulation exercises, guidelines for informing the public, and recommended training for emergency response and health-care workers.

$>$ Response/Implementation activities for controlling the pandemic, minimizing deaths and any social disruption it causes, including communication activities. Implementation also involves documenting the current activities and outcomes to determine if any changes need to be made to the response.

$>$ Recovery activities, such as the dismantling of any emergency response centres set up to respond to the pandemic and the introduction of any new services that might be required as a result of the pandemic.

The future role of the government in the health of Canadians is a question that is highly controversial. Despite the evidence that there are inequalities in health among Canadians, framing policy solutions has been difficult. There is recognition in the health discourse that health and wealth of society are correlated. Factors such as higher incomes, improved diets, housing conditions and working conditions are more significant than sanitation or medical advancements (Wilkinson 2006). Socioeconomic factors alone cannot be identified as the direct causes of health illness in an individual. However, despite the improved population health, inequalities still exist. 
The 'inequalities in health' literature suggests four levels of policy initiative in order to help alleviate major health differences in citizens. These suggestions include strengthening individuals, strengthening communities, improving access to essential facilities and services, and encouraging macroeconomic and cultural changes (Petersen 1994).The Inequalities in Health discourse concludes by stating that reducing poverty and monitoring the impact health policies have on the most vulnerable populations is essential in reducing health inequalities. Critics of the Inequalities in Health agenda argue that this is an idealistic goal and that the Canadian government does not have the capacity or ability to implement health policies that will impact socioeconomic circumstances or increase access to crucial services outside the health portfolio, such as improving housing situations or receiving formal education (Petersen 1994).

Van der Maesen and Nijhuis use the complex social situation of the Bronx in the United States to demonstrate the need for an analytical framework that will incorporate the social quality theory and provide a basis for policies and strategies that will change the conditions that will improve or undermine health. They argue that social quality approach is meant to develop a theory in which the social realities of life would be acknowledged in the articulation of public health. It is a known fact that people living in disadvantaged circumstances experience more illness and disabilities (Van der Maesen \& Nijhuis 2000). Van der Maesen \& Nijhuis defined social quality as "the extent to which citizens are able to 
participate in the social and economic life of their communities under conditions which enhance their well being and individual potential. In order to be enabled to participate (or to enjoy at least a minimum level of social quality), citizens have (i) to have access to an accepted minimum level of economic security, (ii) to experience a basic level of social inclusion, (iii) to live in a community which exhibits social cohesion and (iv) to be empowered to develop their competencies" (Van der Maesen \& Nijhuis 2000: 138).

Using the Social quality theory in relation to health could contribute to improving the physical conditions and social systems that can affect the health of the community. The relationship between social systems, such as educational institutions, cultural systems, economic systems, labour market, access to health resources, etc., and the subjects can create conditions that can affect the health of that community. In order to develop effective public health policies that will improve the health conditions of those who are often marginalized and forgotten, the Public Health Agency and other government departments need to work together with minority groups and community organizations in order to improve the health of these marginalized communities. As demonstrated during the SARS outbreak, the Kashechewan water crisis and Hurricane Katrina, minority groups are often forgotten, discriminated against or completely ignored. 


\section{Conclusion}

This thesis has explored public health ideologies and mechanisms of regulating health. In investigating historical case studies around disease such as the bubonic plague, Spanish Flu and AIDS, I argued that moral regulations were more overt and external State interventions, such as military quarantine measures. Moral regulation of health issues and disease still exists today, however in a more internalized means. For example, health promotion discourse and risk discourse play an important role in self-regulation of the body through the use of 'neutral' language and the perception of legitimacy. The State plays an active role in both historical and current public health case studies. Laws both formal and informal, provides a means to ensure a moral social order in society (Hunt 1999, Helwig and Jasiubedzka, 2001, Peterson 1997). What is important to recognize is the idea that choices that may not necessarily conform to mainstream societies are not necessarily 'immoral' or 'bad' as it may be considered. Health promotion builds itself on the obvious 'good' vs. 'bad' dualism; however these ideas may not always reflect the true everyday realities and circumstances of stigmatized groups.

Health researchers, practitioners and policy developers also need to be more reflective and devote more attention to the ontological aspects of their activities and decisions. They need to be reflexive in their belief system around health, knowledge, practices, assumptions, binary comparisons and be critical in their use of language. There should be an acknowledgement that there could be 
other alternatives to bodily practices practiced in society that may not be the dominant norm governed by social institutions and preached by health experts. An understanding that there is not one 'truth' or way around health practices or beliefs is needed as well as a safe space in society that will accept differences and diversity and articulate one's voice and choice. 


\section{Bibliography}

Abercrombie, N., Hill, S. \& Turner, B. (2000). The Penguin Dictionary of Sociology: $4^{\text {th }}$ Edition. New York: Penguin Books.

Allen, B. (1999). Power/Knowledge. In Karlis Racevskis (Ed.), Critical Essays on Michel Foucault (chapter two). New York: G.K. Hall and Co.

Allen, L. (2001). Disease and History: Must the Past be Prologue? Body Positive Magazine, Retrieved September 17, 2006, from http://www.cdcfoundation.org/index.aspx

Armstrong, D. (1995). Public Health Spaces and the Fabrication of Identity, Sociology, 27: 393-410.

Bancroft, A. (2001). Globalisation and HIVIAIDS: Inequality and the boundaries of a symbolic epidemic. Health, Risk \& Society, 3(1), 89-91, 94-97.

Blendon, R., Benson, J., DesRoches, C., Raleigh, E. \& Taylor-Clark, K. (2004). The Public's Response to Severe Acute Respiratory Syndrome in Toronto and the United States. Harvard School of Public Health, 925-930.

Brandt, A. (1997). Behavior, Disease, and Health in the Twentieth-Century United States: The Moral Valence of Individual Risk. In A. Brandt \& P. Rozin (Eds.), Morality and Health. New York: Routledge Press.

Brandt, A. \& Rozin, P. (1997). Morality and Health. New York: Routledge Press.

Campbell, A. (2005, April 5). The SARS commission second interim report:

SARS and public health legislation. Retrieved November 1, 2006, from http://www.sarscommission.ca/index.html

Carleton University, (2006). Smoke-free Campus, Retrieved March 29 2007, from http://www.now.carleton.ca/2006-09/1318.htm

Cava, M., Fay, K., Beanlands, H., McCay, E. \& Wignall, R. (2005). Risk

Perception and Compliance with Quarantine during the SARS Outbreak. Journal of Nursing Scholarship, 37(4): 343-347.

CBC News (2006). Indepth Federal Budget: Security, Crime \& Military, Retrieved September 20, 2006, from www.cbc.ca/news/background

Craddock, S. (2000). City of Plagues: Disease, Poverty and Deviance in San Francisco. Minnesota: University of Minnesota Press. 
Crotty, P. (1995). Good Nutrition? Fact and Fashion, in Dietary Advice, Allen and Unwin, Sydney: NSW.

Dean, M. (1999). Governmentality: Power and Rule in Modern Society. London: Sage Publications.

Fidler, D. (2004). Germs, Governance, and Global Public Health in the Wake of SARS. Journal of Clinical Investigation, 113 (6):799-804.

Fischer, B. \& Poland, B. (1998). Exclusion, 'risk', and social control - reflections on community Policing and public health. Geoforum, 29: 187-197.

Foucault, M. (1965). Madness and Civilization: A History of Insanity in the Age of Reason, R. Howard (Trans). London: Tavistock.

Foucault, M. (1975). Discipline and Punish: the birth of the Prison, Alan Sheridan (Trans in 1977). New York: Pantheon Books.

Foucault, M. (1980). Power/Knowledge: Selected Interviews \& Other Writings 1972-1977, (Ed.) Colin Gordon. New York: Pantheon Books.

Foucault, M. (1991). Governmentality. In G. Burchell, C. Gordon and P. Miller (Eds.), The Foucault Effect: Studies in Governmentality. London: Harvester

Galor, O. \& Moav, O. (2005). Natural Selection and the Evolution of Life Expectancy, Minerva Center for Economic Growth, Paper No. 02-05, Retrieved October 10, 2006, from http://ssrn.com/abstract=563741

Haldrup,M., Koefoed, L. \& Simonsen, K. (2006). Practical Orientalism - Bodies, Everyday Life and the Construction of Otherness. Human Geography, 88(2), 173-184.

Health Canada, (2006). Emergency Response Plan, Retrieved August 3, 2006 , from http://www.hc-sc.gc.ca/ed-ud/respond/index e.html

Helwig, C. \& Jasiobedzka, U. (2001). The Relation between Law and Morality: Children's Reasoning about Socially Beneficial and Unjust Laws, Child Development, 72(5):1382-1393.

Hunt, A. \& Wickham, G. (1994). Foucault and Law. London. Pluto Press.

Hunt, A. (1999). Governing Morals: A Social History of Moral Regulation. Cambridge: University Press.

James, C. (1995). Seeing Ourselves: Exploring Race, Ethnicity and Culture. Toronto: Thompson Educational Publications. 
Kohler, N. \& Righton, B. (2006, April). Overeaters, smokers and drinkers: the doctor won't see you now. Macleans Magazine.

Kreiser, C. (2006). 1918 Spanish influenza outbreak: the enemy within, History Magazine, December 2006.

Lemke, T. (2002). Foucault, Governmentality, and Critique. Rethinking Marxism, 14(3): 49-64.

Leichter, H. (2003). 'Evil habits' and 'personal choices': assigning responsibility for health in the 20th century. Millbank Quarterly, 81, 603-626.

Leung, C. \& Guan, J. (2004) Yellow Peril Revisited: Impact of SARS on the Chinese and Southeast Asian Canadian Communities. Chinese Canadian National Council.

Lewis, R. (1996). Gendering Orientalism. London: Routledge Press.

Lupton, D. (1994). Moral Threats and Dangerous Desires: AIDS in the News Media. London: Taylor \& Francis Publishers.

Lupton, D. (1995). The Imparative of Health: Public Health and the Regulated Body. London: Sage Publications.

Lupton, D. (1999). Risk. London: Routledge.

Marmor, T. \& Barer, M. (1994). Why Are Some People Healthy and Others Not? New York: Aldine Transaction.

McGillis, L., Hall, L., Angus, J., Peter, E., O'Brien-Pallas, L., Wynn, F., \& Donner, G. (2003). Media Portrayal of Nurses' Perspectives and Concerns in the SARS Crisis in Toronto. Journal of Nursing Scholarship, 35: 211-216.

McGillivray, D. (2005). Fitter, Happier, More Productive: Governing Working Bodies through Wellness. Culture and Organization, 11(2): 125-138.

Myrick, R. (2003). Typesetting Desire: A Critical Reading of Mainstream Press Construction of Gay Identity as Disease. In Linda Fuller (Ed.), Media-Mediated AIDS. New Jersey: Hampton Press.

Mysko, B. (2004). HIVIAIDS in the Courts. HIVIAIDS Policy and Law Review, 9(3):53-54. 
Naylor, D. (2003). Learning from SARS: renewal of public health in Canada. A Report of the National Advisory Committee on SARS, Public Health (Health Canada).

Nettleton S. \& Bunton R. (1995). Sociological critiques of health promotion. In: R. Bunton, S. Nettleton \& R. Burrows (Eds.), The sociology of health promotion. Critical analyses of consumption, lifestyle and risk. Routledge, London.

Oxfordshire Health Archives, (2006). Retrieved March 22, 2006, from http://www.oxfordshirepct.nhs.uk/news/2006/default.aspx

Palmer, A. (2004). Disease overview - Influenza, CSF Medical Communications, 1(9): 316-328.

Petersen, A. (1994). Community development in health promotion: empowerment or regulation? Australian Journal of Public Health, 18, 213-217.

Petersen, A. (1997). Risk, governance and the new public health, In A. Petersen \& R. Bunton (Eds.), Foucault, Health and Medicine. London: Routledge.

Pouchelle, M. (1990). The Body \& Surgery in the Middle Ages. New Brunswick: Rutgers University Press.

Public Health Agency of Canada, (2007). Retrieved September 2006 at http://www.phac-aspc.gc.ca/hp-ps/index.html

Rose, N. (1996). Inventing Ours Selves. Cambridge: Cambridge University Press.

Rose, N. (1999). Powers of Freedom: reframing political thought. Cambridge: Cambridge University Press.

Rosenberg, C. (1997). Banishing risk: Continuity and change in the moral management of disease. In A. Brandt \& P. Rozin (Eds.), Morality and Health. New York: Routeledge.

Rozin, P. (1997). Moralization. In A. Brandt \& P. Rozin (Eds.), Morality and Health. New York: Routeledge.

Said, E. (1979). Orientalism. New York: Pantheon.

Said, E. (2004). Orientalism Once More, Development and Change, 35:869-879.

Saguy, A. \& Riley, K. (2005). Weighing Both Sides: Morality, Mortality, and Framing Contests over Obesity. Journal of Health Politics, Policy and Law, 30(5):869-923. 
Sandford, S. \& Ali, H. (2005). The New Public Health Hegemony: Response to Severe Acute Respiratory Syndrome (SARS) in Toronto. Social Theory \& Health, $1-21$.

Shah, N. (2001). Contagious Divides: Epidemics and Race in San Francisco's Chinatown. Berkeley: University of California Press.

Shohat, E. \& Stam, R. (1994). Unthinking Eurocentrism: Multiculturalism and the Media. New York: Routledge Press.

Tajfel, H. \& Turner, J. (1986). The social identity theory of inter-group behaviour. In S. Worchel \& L. W. Austin (Eds.), Psychology of Intergroup Relations.

Chigago: Nelson-Hall

Time Magazine (February 9, 2004). Times Magazine Online, Retrieved September 2006 at http://www.time.com/time/asia/covers/501040209

Thomas, K. (1997). Health and Morality in Early Modern England. In A. Brandt and P. Rozin (Eds.).Morality and Health. United States: Routledge.

Turner. B. (1992). Regulating Bodies. London: Routledge.

Turner, B. (1997). Foreword: From Governmentality to Risk, Some Reflections on Foucault's Contribution to Medical Sociology In A. Petersen \& R. Bunton (Eds.), Foucault Health and Medicine. Routledge: London.

Van der Maesen, J. \& Nijhuis, H. (2000). Continuing the debate on the philosophy of modern public health: social quality as a point of reference. Journal of Epidermal Community Health, 54: 134-142.

Valverde, M. (1991). The Age of Light, Soap, and Water: Moral Reform in English Canada, 1885-1925. Toronto: McClelland \& Stewart Inc.

Watts, S. (1997). Epidemics in History: Disease, Power, and Imperialism. New Haven and London: Yale University Press.

Wilkinson, R. \& Marmot, M. (2003). The Solid Facts: Social Determinants of Health, World Health Organization. 